\title{
Toward a contagion-based model of mobile banking adoption
}

\author{
Walid Chaouali
}

Faculty of Economics and Management of Sfax, Sfax, Tunisia, and

Kamel El Hedhli

Qatar University, Doha, Qatar

\begin{abstract}
Purpose - The purpose of this paper is to address the following question: Can a bank capitalize on its well-established self-service technologies (SSTs) in order to entice customers to adopt a newly introduced SST, namely, mobile banking? More specifically, it proposes an integrative model that simultaneously investigates the transference effects of attitudes, trust and the contagious influences of social pressures on mobile banking adoption intentions.
\end{abstract}

Design/methodology/approach - Structural equation modeling is applied to data collected from banks' clients who are actually non-users of mobile banking.

Findings - The results indicate that attitude toward and trust in mobile banking along with coercive, normative and mimetic pressures are key antecedents to mobile banking adoption intentions. In addition, attitudes toward automated teller machines (ATMs) and online banking significantly predict attitude toward mobile banking. The results also support the effects of trust in ATMs as well as trust in online banking on trust in mobile banking. Moreover, predicted differences in the relative effects of attitude and trust are supported. Particularly, attitude toward online banking has a stronger impact on attitude toward mobile banking compared to the impact of attitude toward ATMs. In the same vein, the effect of trust in online banking on mobile banking is significantly stronger than the effect of trust in ATMs.

Practical implications - The study's results hint at some practical and worthwhile guidelines for banks that can be leveraged in communication campaigns aiming at boosting the adoption rates of mobile banking. Banks can take advantage of the transference effects of the established attitudes toward and trusting beliefs in their mature SSTs as well as the contagious social influences in inducing the adoption of a newly introduced SST.

Originality/value - The present study represents a first step toward generating new insights into the role of the joint effects of attitudes, trust and social influences in the adoption of a new SST.

Keywords Mobile banking, Trust transfer, Adoption intentions, Attitude transfer,

Self-service technologies, Social contagion

Paper type Research paper

\section{Introduction}

The proliferation of information and communication technologies prompts companies to diversify and extend their distribution channels in order to better serve their customers and inherently gain a competitive edge (Verhagen and van Dolen, 2009). Channels' extension is indeed becoming a standard business practice in use by many firms as much as it is instrumental in enhancing their existing business processes and positively affecting their bottom lines (Yang et al., 2013). Nowadays, self-service technologies (SSTs)[1] are massively provided and used by many organizations and institutions. Needless to say, SSTs are reshaping the relationship between customers and organizations (Curran and Meuter, 2007). In fact, technology infusion brings organizations closer to their clients through the creation of customized, flexible and delightful service encounters

(C) Walid Chaouali and Kamel El Hedhli. Published by Emerald Publishing Limited. This article is published under the Creative Commons Attribution (CC BY 4.0) licence. Anyone may reproduce, distribute, translate and create derivative works of this article (for both commercial and non-commercial purposes), subject to full attribution to the original publication and authors. The full terms of this licence may be seen at http://creativecommons.org/licences/by/4.0/legalcode

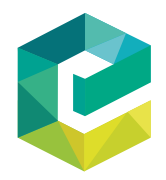

International Journal of Bank Marketing Vol. 37 No. 1, 2019 pp. $69-96$

Emerald Publishing Limited 0265-2323 
IJBM

37,1

(Bitner et al., 2000). Aware of the benefits of SSTs (Bitner et al., 2000; Curran and Meuter, 2007), firms are relentlessly trying through marketing campaigns to entice their clients to adopt these SSTs.

The banking industry is a case in point since it is one of the leading sectors in terms of SST offerings (cf. Curran and Meuter, 2007). Banks rely on different technology-based service encounters such as automated teller machines (ATMs) and online banking, and more recently mobile banking. Particularly, banks have started to provide mobile banking to enable customers to perform banking services at any place and time via their mobile devices. Nevertheless, despite the tremendous efforts of banks in urging customers to adopt mobile banking and contrary to the overly optimistic expectations of mobile banking advocates, the adoption of mobile banking is still, surprisingly, at its infancy level and growing at a slower pace. At a global level, only 15 percent of bank customers use mobile devices to handle their banking-related transactions, 17 percent in North America, 22 percent in Latin America, 16 percent in Europe, 2 percent in emerging Asia, 24 percent in developed Asia and 11 percent in the Middle East and North Africa (Kantar TNS, 2016). Understanding what factors may encourage customers to adopt mobile banking could thus provide insights on how banks can reverse such a timid tendency. One of the objectives of the current study is to investigate some of the factors that facilitate mobile banking adoption. Particularly, it is worthy to explore how a bank can capitalize on its well-established channels in order to boost the adoption rates of a newly emerged channel.

Prior research adopted either an attitudinal perspective (Curran and Meuter, 2007; Shi et al., 2008) or a trust-based perspective (Bock et al., 2012; Wang et al., 2013) in developing SST adoption models. However, our literature review cannot identify a single study where both perspectives are simultaneously considered. Also, empirical research on the roles of social factors in SST adoption is rather scarce and fragmented. This study endeavors to suggest an integrative model which investigates the joint effects of attitudes, trust and social pressure on SST adoption. We believe that simultaneously considering these contagious effects better predict adoption intentions. The extant literature also lacks empirical research on the relative impact of these effects on the adoption of a new SST. This study empirically explores their differential effects on mobile banking adoption.

Although customers are multi-channel users, little academic research embraces SST adoption from a multi-channel perspective that takes into account the interplay and interactions between different channel platforms (Chiou and Shen, 2012; Curran and Meuter, 2007; Yang et al., 2013). The current study, as opposed to prior research, does not consider a new channel (mobile banking) as a stand-alone. Instead, it explicitly addresses the transference[2] effects of the preceding SSTs to which customers are accustomed (cf. Yang et al., 2013). As such, another contribution of this study is to investigate the extent to which preceding SSTs (e.g. ATMs, online banking) already adopted by customers play a role in facilitating the adoption of a newly introduced SST such as mobile banking.

Research shows that social pressure plays a significant role in inciting customers to adopt new products, technologies and channels (Al-Ajam and Md Nor, 2015; Andrews and Bianchi, 2013; Brown et al., 2006, 2010; Shi et al., 2008; Zhou, 2011). However, social pressure, in the context of new SST adoption, is restricted to social acceptance (i.e. others' approval) (Ramayah et al., 2009). Such monolithic conceptualization precludes other aspects of social pressure and does not inherently capture the whole picture of social pressure's effects on the customers' adoption of SSTs (Bhattacherjee, 2000; Ramayah et al., 2009). This study proposes considering other aspects of social pressure along with others' approval in order to better understand the role of social influences in the adoption of a new SST.

To address the aforementioned research voids, we propose an integrative conceptual model that considers the simultaneous effects of attitudes, trust and social influences on mobile banking adoption. Then, we describe the study's methodology. Next, we test the 
research hypotheses and report the results. Then, we discuss the findings along with their theoretical and managerial implications. Last, we close with the study's limitations as well as directions for future research.

\section{Conceptual framework: research hypotheses}

\subsection{Conceptual model}

This study's model is rooted in the theory of reasoned action (TRA) which suggests that behavioral intentions are derived from attitudes and social influences (Fishbein and Ajzen, 1975). Furthermore, the study builds on the SSTs intention to change the behavior model (Curran and Meuter, 2007), trust transference theory (Lee et al., 2007) and social contagion research (Shi et al., 2008) to investigate three contagion-based antecedents to mobile banking adoption: attitude contagion, trust contagion and social contagion. This study states that those contagious antecedents are instrumental in predicting customers' intentions to adopt a new channel. The storyline of this study's model (see Figure 1) is straightforward: adoption of mobile banking will result from favorable attitudes toward mobile banking, trust in mobile banking, as well as coercive, normative and mimetic social influences. Particularly, the favorable attitudes toward and the trust in mobile banking are fostered by preceding favorable attitudes toward and trust in ATMs and online banking. The model also includes three control variables, namely, age, gender and the level of education since previous research shows that they are significantly related to intention to adopt mobile banking (e.g. Shaikh and Karjaluoto, 2015).

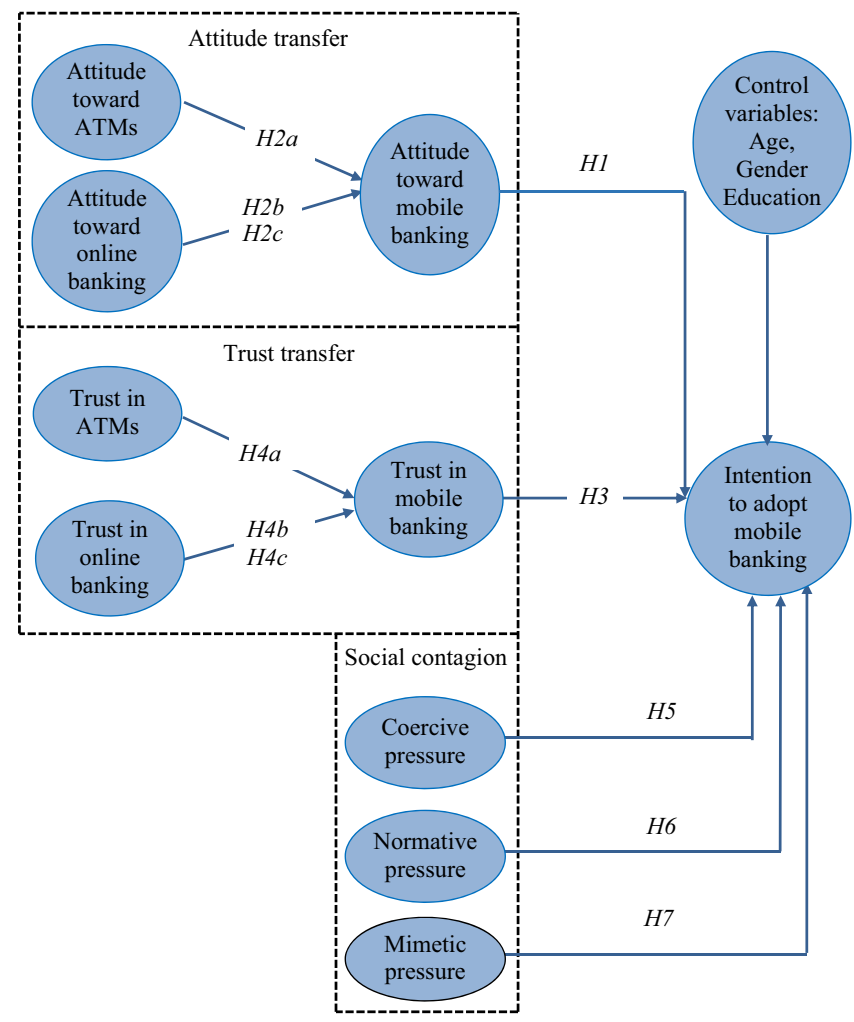

Figure 1. Conceptual model 
IJBM

37,1

\subsection{Research hypotheses}

The following sections articulate the hypotheses regarding the relationships alluded to in the study's model.

2.2.1 Attitude transfer. An attitude, generally speaking, refers to "a psychological tendency that is expressed by evaluating a particular entity with some degree of favor or disfavor" (Eagly and Chaiken, 1993, p. 1). With respect to the context of this study, attitude toward mobile banking refers to the extent to which mobile banking is favorably or unfavorably valued by a customer[3] (Schierz et al., 2010). Extensive research in social psychology and marketing supports the role of attitudes in predicting behavioral intentions (Fishbein and Ajzen, 1975; Ha and Stoel, 2009; Muk and Chung, 2015; Robinson et al., 2005). Also, the link between attitudes and adoption intentions is well-established in multi-channel research (Curran and Meuter, 2007; Schierz et al., 2010). Consequently, one can expect that customers are likely to have intentions to adopt mobile platforms in performing their banking transactions as long as they have first developed favorable attitudes toward this channel. Accordingly, one can hypothesize the following:

H1. There is a positive relationship between attitude toward mobile banking and intention to adopt mobile banking.

A great deal of research informs that multiple and independent attitudes coexist and affect behavioral patterns in a sequential process (Bagozzi, 1993). Attitude formation and change literature provides several accounts of the transference of attitudes from one entity/object to another. For example, advertising research has shown that attitude toward the advertisement predicts attitude toward the brand (MacKenzie et al., 1986; Mitchell and Olson, 1981; Shimp, 1981). The affect-referral heuristic theory may serve as a sound explanation for the attitude contagion phenomenon (Shimp, 1981). This theory indicates that people, when confronted with a new product/service, tend to mainly make their evaluations and adoption decisions on heuristic cues that "may simply involve the elicitation from memory of an overall evaluation or affect" (Shimp, 1981, p. 11). This assumption is also corroborated by the entitativity notion which "refers to the extent to which a group of entities is perceived as being bonded together" (Wang et al., 2013, p. 1397) and posits that "once an initial impression of one [entity] is formed, other [entities] are perceived in terms of that impression, and information about them is processed in such a manner as to try to confirm the impression" (Stewart, 2003, p. 7). This line of reasoning is also akin to the notion of "first impression" in social psychology literature. That is if the first impression (or experience) is positive, further information processing is likely to be biased in the same positive direction (cf. Varvoglis and Sirgy, 1984). Transposed to the study's context, if a customer has, for example, positive attitude and experience with online banking, he/she is likely to form favorable attitudes toward mobile banking (first impression) without even a prior experience with it.

In line with the theories invoked above, Xie et al. (2008) find that adoption is shaped by an overall attitude which is inherently a function of other distinct attitudes. More related to the scope of this study, in new e-channels adoption research, Curran and Meuter (2007) develop the SSTs intention to change the behavior model to account for the interplay between the actual used channels and the unfamiliar (new) e-channel to be potentially adopted. More precisely, they argue that favorable attitudes toward mature e-touchpoints will affect the attitude toward an unfamiliar e-channel. In this sense, a "halo effect" is likely to occur assuming that positive evaluations of existing e-channels will spill over onto appraisals of the new e-channel (Klein and Dawar, 2004).

Previous studies provide evidence on attitude transfer in a multi-channel context. Albesa (2007) carries out a study which explores the factors that affect a person's selection of 
bank channels. He finds that the knowledge and perceived convenience of the electronic channels (ATMs and online) strongly undermine the preference for using the traditional channel. In their qualitative research, Bobbitt and Dabholkar (2001) propose a conceptual framework in which they investigate how attitudes toward using technology in general and attitudes toward SST options shape attitudes toward using a specific SST. Curran and Meuter (2007) clearly demonstrate that attitudes develop in a hierarchical way. Indeed, they find that several attitudes toward specific bank channels determine customers' attitudes toward the bank and SSTs in general, which in turn affect their perceptions of the enjoyment, utility and social acceptance of the new SST. Eriksson and Nilsson (2007) find that overall multi-channel satisfaction influences users' continual use of online banking. Flavián et al. (2006) show that the sociodemographic characteristics and perceptions of traditional bank channels affect customer decisions to adopt online banking. Patsiotis et al. (2013) suggest that online banking is accepted in a hierarchical fashion. It is facilitated first by the familiarity with the internet medium and then by online shopping experience. In the same vein, Reinders et al. (2008) prove that previous SSTs positively impact both attitudes toward using a particular SST and attitudes toward the service provider. Song et al. (2009) demonstrate that usage behavior is transferred indirectly to usage of nonsubstitutable technology products through the transference of the perceptions of ease of use and usefulness. Herhausen et al. (2015) show that multi-channel attributes (online-offline channel integration) affect customer evaluations of quality and risk of the online medium.

Drawing from the above theoretical arguments and empirical evidence, one can safely predict that when a customer has developed favorable attitudes toward ATMs and online banking, which are strengthened through previous fruitful encounters, he/she is incited to intuitively impute, by inference, a favorable attitude toward mobile banking. Accordingly, one can hypothesize the following:

H2a. There is a positive relationship between attitude toward ATMs and attitude toward mobile banking.

H2b. There is a positive relationship between attitude toward online banking and attitude toward mobile banking.

It is worth noting that entitativity research considers that entities "vary along a continuum in the extent to which they are perceived as forming a cohesive unit, rather than forcing such collections to be categorized in a dichotomous fashion as forming a group or not" (Stewart, 2003, p. 7). This implies that the degree of influence of an entity on another is stronger when the degree of assimilation, proximity and integration between them is high (Belanche et al., 2014; Song et al., 2009, 2011). Accordingly, the current research posits that the level of transference varies depending upon the perceived degree of similarity (or "functional consistency") between the mature channel and the new one (cf. Wang et al., 2013). Given that mobile banking is an immediate extension of online banking inasmuch as they share many features, their perceived similarity is high and they are accordingly perceived as a highly entitative couple (Laukkanen, 2016; Wang et al., 2013). Despite their belongingness to the same cohesive group - SSTs - and the same reference source - the same service provider - mobile banking and ATMs are low in entitativity due to the weakness of their perceived tie since they share little with respect to their characteristics (Belanche et al., 2014). Consequently, one can predict that the transferability of attitudes is more pronounced between online banking and mobile banking rather than between ATMs and mobile banking. From this, one can hypothesize the following:

H2c. The impact of a favorable attitude toward online banking on attitude toward mobile banking is greater than the impact of a favorable attitude toward ATMs. 
IJBM

37,1

Notwithstanding the aforementioned discussion, the SSTs' intention to change behavior model only focuses on attitude contagion and does not take into account other relevant contagion effects. The following section suggests extending this model by also considering trust and social contagions as key determinants of mobile banking adoption.

2.2.2 Trust transfer. Trust refers to "the willingness of a party to be vulnerable to the actions of another party based on the expectation that the other will perform a particular action important to the trustor, irrespective of the ability to monitor or control that other party" (Mayer et al., 1995, p. 712). Trust is a crucial factor in risky and uncertain situations or when undesirable outcomes may occur (McKnight et al., 2011). In social exchange research, it is a fact that trust generates higher intentions to depend on another party (Schoorman et al., 2007; Morgan and Hunt, 1994). Trust lessens perceptions of uncertainty and risks and ensures the user's control over technology's subsequent outcomes (Lankton et al., 2016; Zhou, 2012; McKnight et al., 2011). By contrast, the lack of trust makes customers perceive that the unfamiliar product/service would be prone to errors and failures, useless, unpredictable and untrustworthy and thus prevents them from adopting it (Thatcher et al., 2011). Empirical evidence suggests that trust shapes a customer's decision to adopt an innovation (Wang et al., 2013; Zhou, 2012). Accordingly, when a customer has trusting beliefs in mobile banking, he/she is likely to ultimately adopt mobile banking. Thus, one can hypothesize the following:

H3. There is a positive relationship between trust in mobile banking and intention to adopt mobile banking.

By contrast with offline interactions where the formation of trust is facilitated by physical cues (such as the look-and-feel of front-office), trust is hardly established in the wireless environments such as the online and mobile applications (Lee et al., 2007). Indeed, the spatial and temporal separation between the consumers and sellers/service providers will result in both behavioral (sellers/service providers can behave opportunistically) and environmental (wireless environments are technically unpredictable) uncertainties (Kuan et al., 2007). Security of private data and financial assets are on the top of the customer's mind due to the possibility of the loss or theft of their mobile devices or malicious software and hacker attacks (Lu et al., 2008). In addition, they may be anxious about potential technical failures, interruptions, delays and execution errors that may abruptly occur (Lee et al., 2007; Lin et al., 2011). Such uncertainties and risks obstruct or delay the formation of initial trust in mobile banking (Lee et al., 2007). To remedy such situations and speed up the adoption process, companies can leverage the established trust resulting from their customers' experiences with preceding SSTs. As such, trust contagion emerges as a catalyst for fostering trust in new channels recently introduced by a given company (Lin et al., 2011).

Trust transfer is defined as "a trust mechanism that one's trust in an unknown person/object can be derived from his trust in a known person/object that has certain association with the unknown person/object" (Wang et al., 2013, p. 1396). In the current context, trust contagion refers to the transferability of trust from mature channels (i.e. ATMs and online banking) to the newly emerged channel (i.e. mobile banking). Hence, trust transfer arises as a key mechanism that facilitates building swift trust in a new SST (Lee et al., 2007; Walden and Browne, 2009). In a multi-channel context, customers rely on their trust in other channels (online banking and ATMs) to form their initial trust in a relatively unfamiliar one (Lin et al., 2011). The categorization theory (Alba and Hutchinson, 1987; Cohen and Basu, 1987) helps to explain how trust travels or propagates from one entity to another. In fact, the memory structures - associated links between memory nodes involving stored positive/negative beliefs about products/services (see Lowry et al., 2008) - are interpreted, recorded and organized throughout repeated experience with online banking and ATMs 
(mature e-channels) and then would be activated and retrieved to develop initial but strong trusting beliefs in mobile banking (new e-channel) (Lowry et al., 2008; Stewart, 2006; Simonin and Ruth, 1998; Keller, 1987, 1993; Loken, 2006; Verhagen and van Dolen, 2009). Such beliefs (about the new products/services) result from the automatic or deliberative projection of constructed mental models that a customer retrieves when he/she is processing new information (Lee et al., 2007). Accordingly, higher trusting beliefs gained over time through the usage of previous SSTs allow individuals to ultimately ascribe higher trust in the mobile channel even before using it (Lee et al., 2007; Lowry et al., 2008). To the extent that prior interactions are perceived as highly trustworthy, they are thus deemed satisfactory "proof sources" (Bock et al., 2012, p. 99). Studies provide empirical evidence regarding trust transfer. Kuan and Bock (2007) demonstrate that offline trust serves as the basis for customers' inferences of online trust. Stewart (2003) shows that perceived similarity and perceived business ties between a known target and an unknown one determine trusting beliefs (in the unknown target). Hahn and Kim (2009) find that offline trust strongly affects confidence in the online retailer. Applying the signaling theory, the findings of Kim et al. (2004) support the idea that the vendor's trustworthy past performance and behavior (in the offline market) build subsequent trust in online medium for potential and repeat customers. By the same token, Kim et al. (2009) assume that the reliability in previous business engagements creates initial trust in mobile banking. Koufaris and Hampton-Sosa (2004) suggest that perceptions of a firm's trustworthiness are transferable across channels and demonstrate that the perceptions of an offline channel impact the formation of initial online trust. Lee et al. (2007) propose four types of trust transfer process: type 1 (offline to offline), type 2 (offline to online), type 3 (online to online) and type 4 (online to offline). They empirically prove that offline trust affects the structural assurance of the bank's online system. Lee et al. (2011) provide strong evidence for the effect of offline trust in boosting customers' judgments of the online bank. Yap et al. (2010) reveal that traditional bank attributes act as physical cues which influence trust in electronic banking. Lin et al. (2011) indicate that trust in online brokerage services has a significant effect on initial trust in mobile brokerage services. Yang et al. (2015) show that trust in web services strengthens trust in and reduces perceived risk of mobile services. Falk et al. (2007) demonstrate that trust in the service provider influences perceptions of usefulness and risks of the new self-service channel. In this way, customers are likely to develop a sense of trustworthiness in mobile banking as a result of their trust in preceding channels such as ATMs and online banking. Therefore, one can predict:

H4a. There is a positive relationship between trust in ATMs and trust in mobile banking.

$H 4 b$. There is a positive relationship between trust in online banking and trust in mobile banking.

In line with entitativity literature and using the same logic articulated in developing $H 2 c$, one can expect differential effects of trust in ATMs and online banking on trust in mobile banking. That is, customers are likely to associate high levels of trust in mobile banking based more on their trust in online banking than on their trust in ATMs. Accordingly, one can predict that:

H4c. The impact of trust in online banking on trust in mobile banking is greater than the impact of trust in ATMs.

2.2.3 Social contagion. Intentions and behaviors are shaped and modeled as a result of one's observations and learning about his/her social environment. In other words, when a person interacts with other social actors (e.g. individuals, institutions and organizations), he/she is likely to internalize implicit decision rules on which he/she eventually bases his/her future choices (Shi et al., 2008). In line with that very perspective, the social 
IJBM

37,1

contagion theory "documents how ideas, information, and technologies spread throughout a population via social networks" (Sherer et al., 2016, p. 573). Prior research provides empirical evidence supporting the effects of social factors on behavioral intentions (e.g. Angst et al., 2010; Teo et al., 2003; Sherer et al., 2016; Shi et al., 2008). In the context of mobile banking adoption, several studies support the role of social pressure, specifically in the pre-adoption stage (Riquelme and Rios, 2010; Püschel et al., 2010; Martins et al., 2014). A common thread between these studies is that social pressure is defined as "the degree to which an individual perceives that important [or similar] others believe he or she should use the new system" (Venkatesh et al., 2003, p. 451). That is, the role of social pressure is notably limited to social acceptance as initially conceptualized by Fishbein and Ajzen (1975) under the label of "subjective norms." However, this monolithic conceptualization precludes other aspects of social pressure and does not ultimately reflect the whole picture about the effects of social influences on new channel adoption (Angst et al., 2010; Taylor and Todd, 1995; Brown and Venkatesh, 2005). The current study investigates the effects of other types of social influences on customers' intentions to adopt mobile banking.

The social contagion theory implies that people adopt new things (e.g. products and services, technologies, etc.) either involuntarily in order to comply with the requirements of perceived powerful entities (e.g. service providers, suppliers and public authorities) or voluntarily through vicarious learning and positive reinforcement (Walden and Browne, 2009). When social contagion is involuntary (mandatory) in nature, it acts through coercive influences. On the other hand, when it is voluntary, it acts through modeling (i.e. observational learning) and conditioning. Particularly, people are likely to adopt or model a specific behavior in order to ultimately reap the beneficial outcomes of the adopted behavior. This type of social contagion is manifested essentially through two different forms of social influences, namely, normative pressure and mimetic pressure. The following sections articulate the hypotheses regarding the impact of each type of social pressure on customers' intention to adopt mobile banking.

2.2.3.1 Effects of coercive pressure on intention to adopt mobile banking. Coercive pressure refers to individuals' behavioral change dictated by more powerful social actors (Grob and Benn, 2014). People have no choice except performing the behavior imposed by powerful entities (Shi et al., 2008). For example, banks or other government agencies may require customers or citizens to use an exclusive channel (e.g. mobile banking) to perform specific activities such as the payment of electricity bills. That is, a person is likely to adopt a new technology merely in compliance with the requirements of powerful entities or authorities. As such, one can hypothesize the following:

H5. There is a positive relationship between coercive pressure and intention to adopt mobile banking.

2.2.3.2 Effects of normative pressure on intention to adopt mobile banking. Normative pressure refers to one's behavioral change as a result of his/her unconscious desire to comply with social norms. When a specific behavior is the rule or becomes popular among significant and/or similar others (e.g. family, friends and colleagues), non-adopters will "jump on the bandwagon" (Sherer et al., 2016). Otherwise, they would experience the frustration and discomfort of being qualified as "old fashioned" and "laid back" by peers engaged in the novel behavior (Shi et al., 2008). Many customers are motivated by the desire to comply with some standard behaviors which are socially approved (Sherer et al., 2016). The acceptance of mobile banking would be so legitimate, regardless of whether it is useful or not, as to be perceived as the "right" and even the "only" means of conducting financial transactions (Shi et al., 2008). That is, a person is likely to adopt a new technology in order to escape dissonance and experience a sense of self-identification or self-congruity with 
significant and important others. Accordingly, customers find themselves propelled to adopt mobile banking seeking conformity and identification with significant others:

H6. There is a positive relationship between normative pressure and intention to adopt mobile banking.

2.2.3.3 Effects of mimetic pressure on intention to adopt mobile banking. Mimetic pressure "force[s] social actors to behave by seeking examples of established practices and behaviors to follow through voluntarily and consciously copying the same practices and behaviors of other successful and high-status actors" (Shi et al., 2008, p. 276). Mimetic influences, in the context of innovation adoption, are a catalyst through which non-adopters can complete their own missing information, "economize on search costs," "minimize experimentation costs" and "avoid risks that are borne by first-movers" (Teo et al., 2003, p. 22). Particularly, an individual tends to emulate the behaviors of successful individuals owing to the conviction that they are likely to yield higher value (Shi et al., 2008). Furthermore, people are also likely to mimic the behavior of high-status individuals who already adopted the innovation as a way of self-expressiveness and enhancement of their actual self-image (Walden and Browne, 2009). Accordingly, one may believe that "if I adopt that technology then others will like me" or "if I adopt that technology then I can interact with others" (Walden and Browne, 2009, p. 34). Thus, individuals, driven by mimic forces, would adopt mobile banking, when they infer that if popular, admired and respected social actors adopted it, it would, therefore, be beneficial for them as well. Thus, one can predict the following:

H7. There is a positive relationship between mimetic pressure and intention to adopt mobile banking.

\section{Methodology}

\subsection{Data collection and sample characteristics}

Data collection took place over a period of six months from January to June 2016 in France. Regular customers of three major French banks have been intercepted and solicited to participate in the study. The intercept technique has been used in the current study due to the impossibility of obtaining customers' sensitive data - their addresses, e-mails and phone numbers - directly from the bank. The study's sample is made up of French-speaking respondents and accordingly the questionnaire was administered in the French language. Nevertheless, it was initially written in English. Following Brislin (1970), it was first translated into French, then back-translated into English. A comparison between the two versions (the original English version and English back-translated one) showed that they were equivalent, and accordingly the consistency between the English and French versions has been ensured.

The respondents who filled in the survey are non-users of mobile banking. A total of 1,250 questionnaires are fully completed by the respondents. As shown in Table I, 65.8 percent of the participants are male. The majority (43.9 percent) are aged between 31 and 50 years. The sample is fairly well-educated since 46.8 percent of the respondents earned a university degree.

\subsection{Measures}

All the model's constructs are measured based on well-established scales with good psychometric properties. Attitude toward ATMs, attitude toward online banking and attitude toward mobile banking are adapted from Curran and Meuter (2007) and measured on a seven-point semantic differential scales. Trust in ATMs, trust in online banking and trust in mobile banking are adapted from Zhou (2013) and measured on a seven-point Likert scales. Coercive pressure, normative pressure and mimetic pressure are 


\begin{tabular}{|c|c|c|c|}
\hline $\begin{array}{l}1 \mathrm{BBM} \\
371\end{array}$ & Variable & Frequency & Percentage \\
\hline & $\begin{array}{l}\text { Gender } \\
\text { Male } \\
\text { Female }\end{array}$ & $\begin{array}{l}819 \\
426\end{array}$ & $\begin{array}{l}65.8 \\
34.2\end{array}$ \\
\hline 78 & $\begin{array}{l}\text { Age } \\
18-30 \\
31-50 \\
+51\end{array}$ & $\begin{array}{l}335 \\
547 \\
363\end{array}$ & $\begin{array}{l}26.9 \\
43.9 \\
29.2\end{array}$ \\
\hline & $\begin{array}{l}\text { Education } \\
\text { Elementary and high school } \\
\text { Diploma } \\
\text { Undergraduate } \\
\text { Graduate }\end{array}$ & $\begin{array}{l}169 \\
347 \\
146 \\
583\end{array}$ & $\begin{array}{l}13.6 \\
27.9 \\
11.7 \\
46.8\end{array}$ \\
\hline $\begin{array}{l}\text { Table I. } \\
\text { Sample characteristics }\end{array}$ & $\begin{array}{l}\text { Profession } \\
\text { Employee private sector } \\
\text { Employee public sector } \\
\text { Self-employed }\end{array}$ & $\begin{array}{l}352 \\
632 \\
261\end{array}$ & $\begin{array}{l}28.2 \\
50.8 \\
21\end{array}$ \\
\hline
\end{tabular}

adapted from Shi et al. (2008) and measured on a seven-point Likert scales. Three-item seven-point Likert scales are adapted from Venkatesh et al. (2008) to measure customers' intentions to adopt mobile banking. All Likert scales range from 1 (strongly disagree) to 7 (strongly agree). All the model's constructs were captured by three reflective items. Table II shows a complete list of all the individual items of each construct used in the study.

It can be noted that each construct in the model is measured with three items. Although the use of three items is the minimum threshold as a general rule for the number of items per construct, it is considered as a substantial limitation in covariance-based (CB)-structural equation modeling (SEM) (e.g. LISREL) when all constructs in the overall model are measured with three items (Hair et al., 2014). However, this is not the case in variance-based SEM (e.g. SmartPLS). Indeed, CB-SEM needs some requirements regarding model specification, identification and nonconvergence (Hair et al., 2011). These issues are related to the order condition of statistical identification (Hulin et al., 2001). Accordingly, in just-identified models (three-item measures per construct), the number of unique covariance and variance terms equals the number of free parameters (Hair et al., 2014). This means that "all available information is used to generate a unique solution for the parameter estimates; there is no remaining information to enable testing of the model" (Diamantopoulos et al., 2012, p. 447). Consequently, this situation has no real meaning since nonconvergent and improper solutions are likely to occur (Anderson and Gerbing, 1984). Unlike CB-SEM, the order condition of identification does not apply in SmartPLS as a variance-based SEM. SmartPLS does not have requirements or constraints regarding the number of items per construct in a model (Hair et al., 2017). Since PLS-SEM is less restrictive regarding the constructs' measurement properties, three-item measures per construct can be safely used (Hair et al., 2011, 2014). This can explain the increasing number of models with three items per construct (Amin et al., 2016; Hoffmann and Ketteler, 2015).

\subsection{Multicollinearity and common method bias}

The variance inflation factor values are well below the threshold of 5 (Lin et al., 2014), ranging from 1.001 to 2.732 for all the independent variables. These results indicate that multicollinearity is not a serious problem. A Harman's single-factor test reveals that the 


\begin{tabular}{|c|c|c|c|}
\hline Construct & Item & Source & $\begin{array}{l}\text { Mobile } \\
\text { hankino }\end{array}$ \\
\hline $\begin{array}{l}\text { Attitude toward } \\
\text { ATMs }\end{array}$ & $\begin{array}{l}\text { Overall, how would you describe your experience? For me, using } \\
\text { ATMs is: } \\
\text { AA1: very bad/very good } \\
\text { AA2: very unpleasant/very pleasant } \\
\text { AA3: strongly dislike/strongly like }\end{array}$ & $\begin{array}{l}\text { Curran and } \\
\text { Meuter (2007) }\end{array}$ & adoption \\
\hline $\begin{array}{l}\text { Attitude toward } \\
\text { online banking }\end{array}$ & $\begin{array}{l}\text { Overall, how would you describe your experience? For me, using } \\
\text { online banking is: } \\
\text { AO1: very bad/very good } \\
\text { AO2: very unpleasant/very pleasant } \\
\text { AO3: strongly dislike/strongly like }\end{array}$ & $\begin{array}{l}\text { Curran and } \\
\text { Meuter (2007) }\end{array}$ & 79 \\
\hline $\begin{array}{l}\text { Attitude toward } \\
\text { mobile banking }\end{array}$ & $\begin{array}{l}\text { Overall, how would you describe your future experience? For me, } \\
\text { adopting mobile banking would be: } \\
\text { AM1: very bad/very good } \\
\text { AM2: very unpleasant/very pleasant } \\
\text { AM3: strongly dislike/strongly like }\end{array}$ & $\begin{array}{l}\text { Curran and } \\
\text { Meuter (2007) }\end{array}$ & \\
\hline Trust in ATMs & $\begin{array}{l}\text { TA1: ATMs are trustworthy } \\
\text { TA2: ATMs keep their promises } \\
\text { TA3: ATMs keep customers' interests first }\end{array}$ & Zhou (2013) & \\
\hline $\begin{array}{l}\text { Trust in online } \\
\text { banking }\end{array}$ & $\begin{array}{l}\text { TO1: online banking is trustworthy } \\
\text { TO2: online banking keeps its promises } \\
\text { TO3: online banking keeps customers' interests first }\end{array}$ & Zhou (2013) & \\
\hline $\begin{array}{l}\text { Trust in mobile } \\
\text { banking }\end{array}$ & $\begin{array}{l}\text { TM1: mobile banking would be trustworthy } \\
\text { TM2: mobile banking would keep its promises } \\
\text { TM3: mobile banking would keep customers' interests first }\end{array}$ & Zhou (2013) & \\
\hline Coercive pressure & $\begin{array}{l}\text { CP1: many of my financing tasks require me to use mobile banking } \\
\text { CP2: many transactions can be accomplished only when using } \\
\text { mobile banking } \\
\text { CP3: my financial interactions with my company, friends and other } \\
\text { businesses force me to use mobile banking }\end{array}$ & Shi et al. (2008) & \\
\hline Normative pressure & $\begin{array}{l}\text { NP1: I have seen what others do using their mobile banking } \\
\text { NP2: many people in my social network (friends, family, } \\
\text { workmates and classmates) use mobile banking } \\
\text { NP3: mobile banking is very visible in my social network (friends, } \\
\text { family, workmates and classmates) }\end{array}$ & Shi et al. (2008) & \\
\hline Mimetic pressure & $\begin{array}{l}\text { MP1: people around me who use mobile banking have more } \\
\text { prestige than those who do not } \\
\text { MP2: people around me who use mobile banking have a high profile } \\
\text { MP3: using mobile banking is a status symbol for people around me }\end{array}$ & Shi et al. (2008) & \\
\hline $\begin{array}{l}\text { Intention to adopt } \\
\text { mobile banking }\end{array}$ & $\begin{array}{l}\text { IA1: I intend to adopt mobile banking in the next months } \\
\text { IA2: I predict I would adopt mobile banking in the next months } \\
\text { IA3: I plan to adopt mobile banking in the next months }\end{array}$ & $\begin{array}{l}\text { Venkatesh et al. } \\
\text { (2008) }\end{array}$ & $\begin{array}{r}\text { Table II; } \\
\text { Constructs' } \\
\text { measurements }\end{array}$ \\
\hline
\end{tabular}

issue of a common method variance bias is minimized in the current study since the majority of the variance is not accounted for by a single factor. In fact, the first factor accounted for 37.22 percent of the variance which is substantially below the critical threshold of 50 percent (Peters et al., 2016; Podsakoff et al., 2003).

\section{Results}

\subsection{Measurement model and psychometric properties}

As shown in Table III, the results indicate that Cronbach's $\alpha \mathrm{s}$ and composite reliabilities are higher than the critical value of 0.70 , demonstrating internal consistency reliability (Hair et al., 2014). All factor loadings are higher than the threshold of 0.70 


\begin{tabular}{llccc}
\cline { 3 - 4 } IJBM & & Cronbach's $\alpha$ & Composite reliability & Average variance extracted (AVE) \\
\cline { 2 - 5 } 37,1 & AA & 0.890 & 0.918 & 0.790 \\
& AO & 0.800 & 0.881 & 0.713 \\
& AM & 0.915 & 0.946 & 0.855 \\
& TA & 0.963 & 0.976 & 0.930 \\
$\mathbf{8 0}$ & TO & 0.955 & 0.971 & 0.917 \\
& TM & 0.969 & 0.980 & 0.941 \\
& CP & 0.888 & 0.925 & 0.804 \\
& NP & 0.803 & 0.878 & 0.707 \\
& MP & 0.882 & 0.907 & 0.767 \\
& IA & 0.744 & 0.853 & 0.659
\end{tabular}

Table III.

Construct reliability and validity
Notes: AA, attitude toward ATMs; AO, attitude toward online banking; AM, attitude toward mobile banking; TA, trust in ATMs; TO, trust in online banking; TM, trust in mobile banking; $\mathrm{CP}$, coercive pressure; $\mathrm{NP}$, normative pressure; MP, mimetic pressure; IA, intention to adopt mobile banking

and are statistically significant. Also, the average variance extracted (AVE) of each construct is greater than the generally accepted value of 0.50 , supporting the convergent validity of all the study's constructs (Hair et al., 2014).

The results presented in Table IV show that the square root of each construct's AVE is greater than its correlations with the other constructs (Fornell and Larcker, 1981). Also, the heterotrait-monotrait (HTMT) ratios of correlations (see Table V) meet the HTMT $_{\text {inference }}$ criterion (all the upper limits of the confidence intervals, resulting from the bootstrapping algorithm are below the threshold of 1 ) and the conservative $\mathrm{HTMT}_{85}$ criterion (all HTMT values are below 0.85). These results altogether lend support to the discriminant validity of all the model's constructs.

\subsection{Structural equations model: hypotheses testing}

The study applies SEM using SmartPLS 3 to test the hypothesized relationships. As shown in Table VI, the model explains 53 percent of the variance in intention to adopt mobile banking, 22.30 percent of the variance in attitude toward mobile banking and 52.10 percent of the variance in trust in mobile banking. In addition, the Stone-Geisser's $Q^{2}$ (Geisser, 1974; Stone, 1974) values are estimated using the blindfolding procedure in order to measure the model's predictive relevance. $Q^{2}$ is "a measure of how well the path model can predict the

\begin{tabular}{|c|c|c|c|c|c|c|c|c|c|c|}
\hline & AA & $\mathrm{AO}$ & $\mathrm{AM}$ & TA & TO & TM & $\mathrm{CP}$ & $\mathrm{NP}$ & $\mathrm{MP}$ & IA \\
\hline AA & 0.889 & & & & & & & & & \\
\hline $\mathrm{AO}$ & 0.029 & 0.844 & & & & & & & & \\
\hline $\mathrm{AM}$ & 0.202 & 0.432 & 0.925 & & & & & & & \\
\hline TA & 0.424 & 0.017 & 0.182 & 0.964 & & & & & & \\
\hline TO & 0.544 & 0.132 & 0.225 & 0.796 & 0.958 & & & & & \\
\hline TM & 0.322 & 0.215 & 0.052 & 0.678 & 0.689 & 0.970 & & & & \\
\hline $\mathrm{CP}$ & 0.511 & 0.152 & 0.133 & 0.641 & 0.735 & 0.596 & 0.897 & & & \\
\hline $\mathrm{NP}$ & 0.071 & 0.544 & 0.664 & 0.179 & 0.279 & 0.298 & 0.219 & 0.841 & & \\
\hline MP & 0.371 & 0.018 & 0.027 & 0.728 & 0.690 & 0.624 & 0.676 & 0.185 & 0.876 & \\
\hline IA & 0.228 & 0.274 & 0.567 & 0.022 & 0.152 & 0.169 & 0.151 & 0.495 & 0.134 & 0.812 \\
\hline
\end{tabular}

Table IV.

Fornell-Larcker criterion

Notes: AA, attitude toward ATMs; AO, attitude toward online banking; AM, attitude toward mobile banking; TA, trust in ATMs; TO, trust in online banking; TM, trust in mobile banking; CP, coercive pressure; NP, normative pressure; MP, mimetic pressure; IA, intention to adopt mobile banking. Diagonal values (in italic) are squared roots of AVE; off-diagonal values are the estimates of inter-correlation between the latent constructs 


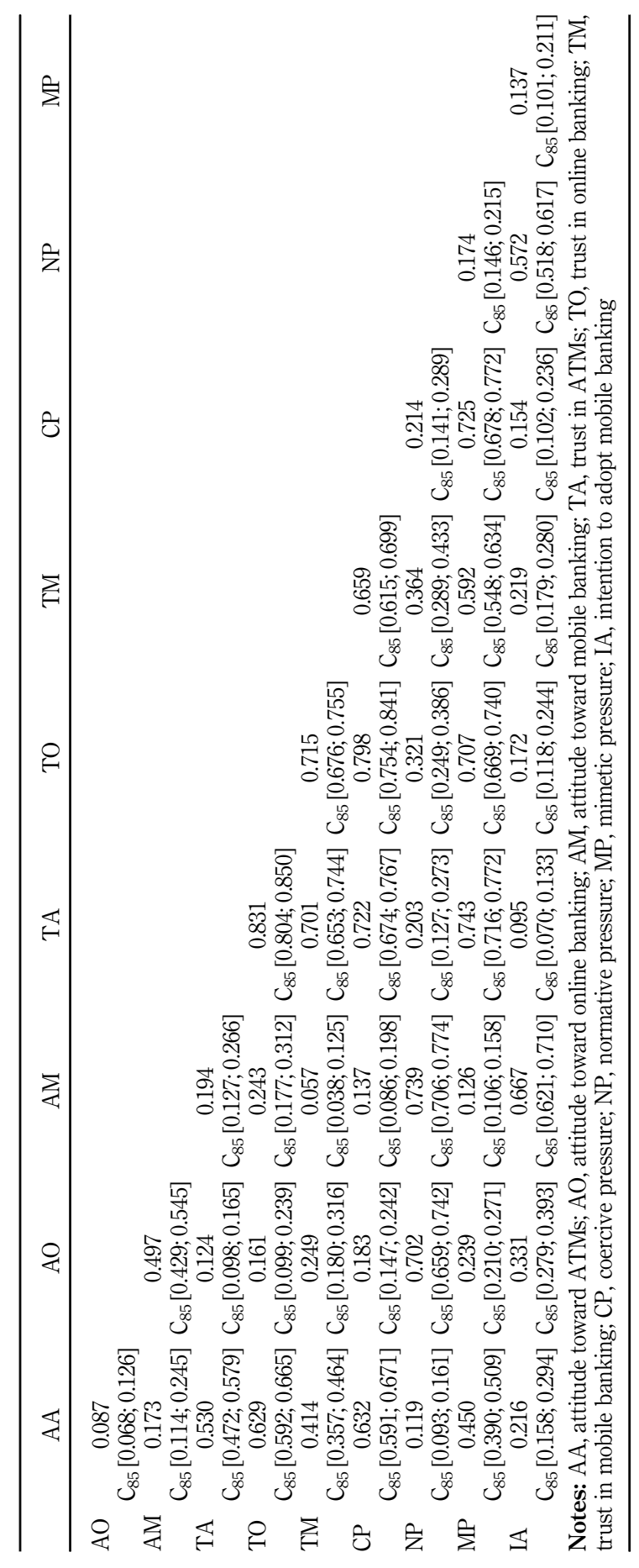

Mobile banking adoption

Table V. Heterotrait-monotrait criterion 


\begin{tabular}{|c|c|c|c|c|}
\hline \multirow{6}{*}{$\begin{array}{l}1 \mathrm{JBM} \\
37,1\end{array}$} & & $\beta$ & $t$ & $f^{2}$ \\
\hline & $\mathrm{AA} \rightarrow \mathrm{AM}$ & 0.19 & 8.181 & 0.046 \\
\hline & $\mathrm{AO} \rightarrow \mathrm{AM}$ & 0.42 & 17.059 & 0.234 \\
\hline & $\mathrm{TA} \rightarrow \mathrm{TM}$ & 0.35 & 8.957 & 0.096 \\
\hline & $\mathrm{TO} \rightarrow \mathrm{TM}$ & 0.40 & 11.016 & 0.126 \\
\hline & $\mathrm{AM} \rightarrow \mathrm{IA}$ & 0.33 & 11.3 & 0.122 \\
\hline \multirow{7}{*}{82} & $\mathrm{TM} \rightarrow \mathrm{IA}$ & 0.58 & 15.881 & 0.375 \\
\hline & $\mathrm{CP} \rightarrow \mathrm{IA}$ & 0.17 & 5.949 & 0.030 \\
\hline & $\mathrm{NP} \rightarrow \mathrm{IA}$ & 0.35 & 11.656 & 0.131 \\
\hline & $\mathrm{MP} \rightarrow \mathrm{IA}$ & 0.30 & 8.301 & 0.094 \\
\hline & & $\mathrm{AM}$ & TM & IA \\
\hline & $R^{2}$ & 0.223 & 0.521 & 0.53 \\
\hline & $Q^{2}$ & 0.189 & 0.489 & 0.34 \\
\hline
\end{tabular}

Table VI.

Results of the structural model
Notes: AA, attitude toward ATMs; AO, attitude toward online banking; AM, attitude toward mobile banking; TA, trust in ATMs; TO, trust in online banking; TM, trust in mobile banking; $\mathrm{CP}$, coercive pressure; $\mathrm{NP}$, normative pressure; MP, mimetic pressure; IA, intention to adopt mobile banking. $\beta$ : path coefficient; $f^{2}$ : effect size; $R^{2}$ : explained variance; $Q^{2}$ : predictive relevance. All path coefficients are significant $(p<0.001)$

originally observed values" (Hair et al., 2014, p. 183). When $Q^{2}$ values are higher than zero, the model has high predictive relevance (Hair et al., 2017). The results indicate that all $Q^{2}$ values are higher than the threshold of zero (attitude toward mobile banking $=0.189$, trust in mobile banking $=0.489$, intention to adopt mobile banking $=0.340$ ), lending support to the predictive relevance of the study's model (cf. Hair et al., 2014).

Furthermore, the $f^{2}$ effect size, which "allows assessing an exogenous construct's contribution to an endogenous latent variable's $R^{2}$ value" (Hair et al., 2017, p. 208), is calculated. Values of 0.02, 0.15 and 0.35 reflect small, medium and large effect, respectively (Hair et al., 2017).

Attitude toward ATMs $(\beta=0.19 ; t=7.989 ; p<0.001)$ and attitude toward online banking ( $\beta=0.42 ; t=17.268 ; p<0.001)$ have significant and positive effects on attitude toward mobile banking. These results support $H 2 a$ and $H 2 b$, respectively. As expected, the impact of attitude toward online banking on attitude toward mobile banking is greater than the impact of attitude toward ATMs. In fact, the results of the effect sizes $\left(f^{2}\right)$ show that attitude toward online banking has the strongest impact on attitude toward mobile banking $\left(f^{2}=0.234\right)$, followed by attitude toward ATMs $\left(f^{2}=0.046\right)$. Therefore, $H 2 c$ is supported too.

Trust in ATMs $(\beta=0.35 ; t=9.031 ; p<0.001)$ and trust in online banking $(\beta=0.40$; $t=10.690 ; p<0.001)$ significantly predict trust in mobile banking. Particularly, the results of the effect sizes $\left(f^{2}\right)$ indicate that trust in online banking mainly predicts trust in mobile banking $\left(f^{2}=0.126\right)$, followed by trust in ATMs $\left(f^{2}=0.096\right)$. These results lend support to $H 4 a-H 4 c$. Attitude toward mobile banking $(\beta=0.33 ; t=11.161 ; p<0.001)$, trust in mobile banking $(\beta=0.58 ; t=16.590 ; p<0.001)$, coercive pressure $(\beta=0.17 ; t=5.677 ; p<0.001)$, normative pressure $(\beta=0.35 ; t=11.515 ; p<0.001)$ and mimetic pressure $(\beta=0.30$; $t=8.408 ; p<0.001)$ significantly and positively predict intention to adopt mobile banking. These results support $H 1, H 3, H 5, H 6$ and $H 7$, respectively. With respect to $f^{2}$, trust in mobile banking has the largest effect $\left(f^{2}=0.375\right)$, followed by normative pressure ( $\left.f^{2}=0.131\right)$, attitude toward mobile banking $\left(f^{2}=0.122\right)$, mimetic pressure $\left(f^{2}=0.094\right)$ and finally coercive pressure $\left(f^{2}=0.030\right)$. Unexpectedly, the results indicate that the control variables have no significant effects on intention to adopt mobile banking.

\subsection{Additional results: the importance-performance map analysis (IPMA)}

We also conducted an IPMA. The IPMA "contrasts the structural model total effects (importance) and the average values of the latent variable scores (performance) to highlight significant areas for the improvement of management activities" (Hair et al., 2014, p. 206). 
It allows a deeper interpretation of the SEM results and particularly aims to enhance the future performance of the variables which have a large importance (in explaining a specific endogenous variable) but a low actual performance (Hair et al., 2014). Table VII shows that trust in mobile banking has both high relevance and relatively high performance. By contrast, normative pressure, attitude toward mobile banking and mimetic pressure have high relevance but low levels of performance. Thus, banks are well-advised to exert more efforts in order to improve the performance of these variables to ultimately boost the adoption rates of mobile banking. Inspection of the IPMA of attitude toward mobile banking reveals that attitude toward online banking has high importance but exhibits low performance. According to the IPMA, trust in mobile banking, trust in online banking and trust in ATMs have high importance but rather low performance. Consequently, banks should focus more on attitude toward online banking, trust in online banking and trust in ATMs to enhance their performances.

\subsection{Additional results: the moderating effects of age and gender}

In addition, the current study examines whether gender and age (different age cohorts) moderate all the linkages in the model. This additional analysis may be a valuable contribution to technology adoption literature and allow a more thorough comprehension of contagion effects. Before running multi-group analysis (PLS-MGA), a measurement invariance of composite models (MICOM) is conducted. The MICOM analysis is a three-step approach: configural invariance (this step is automatically established in SmartPLS), compositional invariance and the equality of composite mean values and variances (Henseler et al., 2016) and is applied to "determine whether significant intergroup differences are due to inter-group differences in constructs, when assessing composite models" (Calvo-Mora et al., 2016, p. 668). The outcomes of the permutation algorithm demonstrate that compositional invariance and the equality of composite mean values and variances are fully established for gender and age-based groups (as shown in Table VIII). As such, the PLS-MGA can be safely conducted. The results show that no moderation effect is found, in line with previous research (Baker et al., 2007). As shown in Table IX, it appears that the model relationships hold true for all customers regardless of their gender and age. This result suggests that the effects of contagion are independent of gender and age.

\begin{tabular}{lcc}
\hline & Importance & Performance (in percentage) \\
\hline Predecessors of IA & & \\
AM & 0.27 & 48.827 \\
TM & 0.47 & 71.2 \\
CP & 0.13 & 41.78 \\
NP & 0.32 & 34.876 \\
MP & 0.24 & 42.722 \\
Predecessors of AM & & \\
AA & 0.22 & 42.820 \\
AO & 0.46 & 44.420 \\
Predecessors of TM & & \\
TA & 0.40 & 63.907 \\
TO & 0.41 & 60.741
\end{tabular}

Notes: AA, attitude toward ATMs; AO, attitude toward online banking; AM, attitude toward mobile banking; TA, trust in ATMs; TO, trust in online banking; TM, trust in mobile banking; $\mathrm{CP}$, coercive pressure; $\mathrm{NP}$, normative pressure; MP, mimetic pressure; IA, intention to adopt mobile banking

Table VII. Importanceperformance map analysis 
IJBM

37,1

MICOM 1 (gender)

Step 2: Comp. inv.

$\begin{array}{lc}\text { Composite } & \text { Corr. c value }(=1) \\ \text { AA } & 0.999 \\ \text { AO } & 1.000 \\ \text { AM } & 1.000 \\ \text { TA } & 1.000 \\ \text { TO } & 1.000 \\ \text { TM } & 1.000 \\ \text { CP } & 0.999 \\ \text { NP } & 1.000 \\ \text { MP } & 0.999 \\ \text { IA } & 1.000\end{array}$

$95 \%$ CI

[0.968; 1.000]

$[0.997 ; 1.000]$

[1.000; 1.000$]$

$[1.000 ; 1.000]$

$[1.000 ; 1.000]$

[1.000; 1.000$]$

[0.967; 1.000$]$

[0.998; 1.000$]$

$[0.693 ; 1.000]$

Step 3a: equality of composite mean values

Composite Diff. in the composite's mean value $(=0)$

$\begin{array}{lr}\text { AA } & 0.020 \\ \text { AO } & -0.028 \\ \text { AM } & -0.035 \\ \text { TA } & 0.020 \\ \text { TO } & 0.022 \\ \text { TM } & 0.036 \\ \text { CP } & -0.022 \\ \text { NP } & -0.032 \\ \text { MP } & -0.012 \\ \text { IA } & -0.003\end{array}$

$[0.999 ; 1.000]$

$95 \%$ CI

$[-0.121 ; 0.117]$

$[-0.116 ; 0.121]$

$[-0.120 ; 0.115]$

$[-0.112 ; 0.124]$

$[-0.117 ; 0.115]$

$[-0.118 ; 0.118]$

[-0.118; 0.114]

[-0.113; 0.112]

[-0.126;0.115]

[-0.116; 0.111]

Step 3b: equality of variances

$95 \% \mathrm{CI}$

[-0.133; 0.145]

$[-0.137 ; 0.137]$

[-0.100; 0.103]

[-0.146; 0.150$]$

[-0.138; 0.134]

$[-0.156 ; 0.181]$

[-0.115; 0.128]

[-0.114;0.119]

$[-0.115 ; 0.121]$

$[-0.142 ; 0.145]$

MICOM 2 (age <30 and age > 30)

Step 2: Comp. inv.

$\begin{array}{lc}\text { Composite } & \text { Corr. c value }(=1) \\ \text { AA } & 1.000 \\ \text { AO } & 1.000 \\ \text { AM } & 1.000 \\ \text { TA } & 1.000 \\ \text { TO } & 1.000 \\ \text { TM } & 1.000 \\ \text { CP } & 0.999 \\ \text { NP } & 1.000 \\ \text { MP } & 0.997 \\ \text { IA } & 1.000\end{array}$

Step 3a: equality of composite mean values

Composite Diff. in the composite's mean value $(=0)$

$\begin{array}{lr}\text { AA } & 0.048 \\ \text { AO } & 0.068 \\ \text { AM } & 0.032 \\ \text { TA } & -0.021 \\ \text { TO } & -0.029\end{array}$

Table VIII.

TO
$95 \%$ CI

$[0.959 ; 1.000]$

$[0.996 ; 1.000]$

$[1.000 ; 1.000]$

$[1.000 ; 1.000]$

$[1.000 ; 1.000]$

[1.000; 1.000$]$

[0.938; 1.000$]$

[0.997; 1.000]

$[0.443 ; 1.000]$

[0.999; 1.000]

95\% CI

[-0.130; 0.124$]$

[-0.126; 0.122]

[-0.124; 0.122$]$

[-0.117; 0.125$]$

[-0.117; 0.121$]$
Comp. inv.?

Yes

Yes

Yes

Yes

Yes

Yes

Yes

Yes

Yes

Yes

Eq. mean values?

Yes

Yes

Yes

Yes

Yes

Yes

Yes

Yes

Yes

Yes

Eq. variances?

Yes

Yes

Yes

Yes

Yes

Yes

Yes

Yes

Yes

Yes

Comp. inv.?

Yes

Yes

Yes

Yes

Yes

Yes

Yes

Yes

Yes

Yes

Eq. mean values?

Yes

Yes

Yes

Yes

Yes

MICOM (gender and age)

(continued) 


\begin{tabular}{lrrr}
\hline TM & -0.017 & {$[-0.126 ; 0.118]$} & Mobile \\
CP & 0.029 & {$[-0.118 ; 0.122]$} & Yes \\
NP & 0.038 & {$[-0.127 ; 0.119]$} & Yes \\
MP & 0.006 & {$[-0.126 ; 0.122]$} & Yes \\
IA & 0.021 & {$[-0.126 ; 0.122]$} & Yes \\
Step 3b: equality of variances & & & \\
Composite & Log. of the composite's variances ratio $(=0)$ & $95 \%$ CI & Eq. variances? \\
AA & 0.043 & {$[-0.155 ; 0.136]$} & Yes \\
AO & 0.039 & {$[-0.152 ; 0.140]$} & Yes \\
AM & -0.029 & {$[-0.108 ; 0.102]$} & Yes \\
TA & 0.010 & {$[-0.176 ; 0.158]$} & Yes \\
TO & 0.038 & {$[-0.149 ; 0.141]$} & Yes \\
TM & 0.031 & {$[-0.185 ; 0.177]$} & Yes \\
CP & 0.019 & {$[-0.143 ; 0.126]$} & Yes \\
NP & 0.017 & {$[-0.129 ; 0.121]$} & Yes \\
MP & 0.020 & {$[-0.140 ; 0.119]$} & Yes \\
IA & -0.038 & {$[-0.173 ; 0.142]$} & Yes
\end{tabular}

MICOM 3 (age <50 and age $>50$ )

Step 2: Comp. inv.

$\begin{array}{lc}\text { Composite } & \text { Corr. c value }(=1) \\ \text { AA } & 0.987 \\ \text { AO } & 1.000 \\ \text { AM } & 1.000 \\ \text { TA } & 1.000 \\ \text { TO } & 1.000 \\ \text { TM } & 1.000 \\ \text { CP } & 0.999 \\ \text { NP } & 1.000 \\ \text { MP } & 0.997 \\ \text { IA } & 1.000\end{array}$

Step 3a: equality of composite mean values

$\begin{array}{lccc}\text { Composite } & \text { Diff. in the composite's mean value }(=0) & 95 \% \mathrm{CI} & \text { Eq. mean values? } \\ \text { AA } & 0.005 & {[-0.128 ; 0.118]} & \text { Yes } \\ \text { AO } & -0.037 & {[-0.129 ; 0.120]} & \text { Yes } \\ \text { AM } & -0.002 & {[-0.119 ; 0.118]} & \text { Yes } \\ \text { TA } & -0.009 & {[-0.123 ; 0.120]} & \text { Yes } \\ \text { TO } & -0.036 & {[-0.121 ; 0.123]} & \text { Yes } \\ \text { TM } & -0.004 & {[-0.121 ; 0.129]} & \text { Yes } \\ \text { CP } & -0.025 & {[-0.122 ; 0.122]} & \text { Yes } \\ \text { NP } & -0.010 & {[-0.119 ; 0.114]} & \text { Yes } \\ \text { MP } & 0.010 & {[-0.131 ; 0.122]} & \text { Yes } \\ \text { IA } & 0.015 & {[-0.118 ; 0.116]} & \text { Yes } \\ \text { Step 3b: equality of variances } & & & \text { Eq. variances? } \\ \text { Composite } & \text { Log. of the composite's variances ratio }(=0) & 95 \% \text { CI } & \text { Yes } \\ \text { AA } & -0.013 & {[-0.137 ; 0.148]} & \text { Yes } \\ \text { AO } & 0.130 & {[-0.131 ; 0.142]} & \text { Yes } \\ \text { AM } & 0.012 & {[-0.096 ; 0.115]} & \text { Yes } \\ \text { TA } & 0.053 & {[-0.138 ; 0.162]} & \text { Yes } \\ \text { TO } & 0.085 & {[-0.137 ; 0.138]} & \text { Yes } \\ \text { TM } & 0.080 & {[-0.170 ; 0.185]} & \text { Yes } \\ \text { CP } & 0.084 & {[-0.120 ; 0.125]} & \text { Yes } \\ \text { NP } & 0.069 & {[-0.118 ; 0.129]} & \text { Yes } \\ \text { MP } & 0.007 & {[-0.140 ; 0.142]} & \text { Yes }\end{array}$

Notes: AA, attitude toward ATMs; AO, attitude toward online banking; AM, attitude toward mobile banking; TA, trust in ATMs; TO, trust in online banking; TM, trust in mobile banking; CP, coercive pressure; $\mathrm{NP}$, normative pressure; MP, mimetic pressure; IA, intention to adopt mobile banking; Corr., correlation; CI, confidence interval; Comp. inv., compositional invariance; Diff., difference; Eq., equal; Log., logarithm 
IJBM
37,1

\begin{tabular}{|c|c|c|c|c|c|c|c|}
\hline & $\beta$ & $p$-value & $\beta$ & $p$-value & $\beta$ diff & $p$-value & Sig. \\
\hline \multicolumn{8}{|c|}{ PLS-MGA (Gender) } \\
\hline & \multicolumn{2}{|c|}{ G1 male } & \multicolumn{2}{|c|}{ G2 female } & \multicolumn{2}{|c|}{$\mathrm{G} 1-\mathrm{G} 2$} & \\
\hline $\mathrm{AA} \rightarrow \mathrm{AM}$ & 0.201 & 0.000 & 0.170 & 0.000 & 0.031 & 0.266 & ns \\
\hline $\mathrm{AO} \rightarrow \mathrm{AM}$ & 0.429 & 0.000 & 0.422 & 0.000 & 0.008 & 0.444 & ns \\
\hline $\mathrm{TA} \rightarrow \mathrm{TM}$ & 0.349 & 0.000 & 0.365 & 0.000 & 0.016 & 0.572 & ns \\
\hline $\mathrm{TO} \rightarrow \mathrm{TM}$ & 0.414 & 0.000 & 0.393 & 0.000 & 0.021 & 0.398 & ns \\
\hline $\mathrm{TM} \rightarrow \mathrm{IA}$ & 0.589 & 0.000 & 0.583 & 0.000 & 0.006 & 0.498 & ns \\
\hline $\mathrm{AM} \rightarrow \mathrm{IA}$ & 0.343 & 0.000 & 0.305 & 0.000 & 0.038 & 0.273 & ns \\
\hline $\mathrm{CP} \rightarrow \mathrm{IA}$ & 0.171 & 0.000 & 0.171 & 0.007 & 0.001 & 0.509 & ns \\
\hline $\mathrm{NP} \rightarrow \mathrm{IA}$ & 0.343 & 0.000 & 0.381 & 0.000 & 0.038 & 0.725 & ns \\
\hline $\mathrm{MP} \rightarrow \mathrm{IA}$ & 0.316 & 0.000 & 0.297 & 0.001 & 0.019 & 0.467 & ns \\
\hline
\end{tabular}

PLS-MGA (age <30 and age > 30)

\begin{tabular}{|c|c|c|c|c|c|c|c|}
\hline 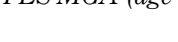 & G3 & & & & & & \\
\hline $\mathrm{AA} \rightarrow \mathrm{AM}$ & 0.208 & 0.000 & 0.183 & 0.000 & 0.025 & 0.315 & ns \\
\hline $\mathrm{AO} \rightarrow \mathrm{AM}$ & 0.425 & 0.000 & 0.428 & 0.000 & 0.002 & 0.507 & ns \\
\hline $\mathrm{TA} \rightarrow \mathrm{TM}$ & 0.354 & 0.000 & 0.354 & 0.000 & 0.000 & 0.493 & ns \\
\hline $\mathrm{TO} \rightarrow \mathrm{TM}$ & 0.409 & 0.000 & 0.406 & 0.000 & 0.002 & 0.487 & ns \\
\hline $\mathrm{AM} \rightarrow \mathrm{IA}$ & 0.352 & 0.000 & 0.322 & 0.000 & 0.030 & 0.328 & ns \\
\hline $\mathrm{TM} \rightarrow \mathrm{IA}$ & 0.588 & 0.000 & 0.587 & 0.000 & 0.001 & 0.496 & ns \\
\hline $\mathrm{CP} \rightarrow \mathrm{IA}$ & 0.183 & 0.001 & 0.166 & 0.001 & 0.017 & 0.398 & ns \\
\hline $\mathrm{NP} \rightarrow \mathrm{IA}$ & 0.337 & 0.000 & 0.363 & 0.000 & 0.025 & 0.649 & ns \\
\hline $\mathrm{MP} \rightarrow \mathrm{IA}$ & 0.317 & 0.000 & 0.306 & 0.000 & 0.011 & 0.427 & ns \\
\hline PLS-MGA (age & $\begin{array}{r}<50 \text { and age } \\
\text { G5 }\end{array}$ & $>50)$ & & & & & \\
\hline $\mathrm{AA} \rightarrow \mathrm{AM}$ & 0.201 & 0.000 & 0.172 & 0.018 & 0.029 & 0.335 & ns \\
\hline $\mathrm{AO} \rightarrow \mathrm{AM}$ & 0.431 & 0.000 & 0.413 & 0.000 & 0.019 & 0.371 & ns \\
\hline $\mathrm{TA} \rightarrow \mathrm{TM}$ & 0.344 & 0.000 & 0.377 & 0.000 & 0.033 & 0.660 & ns \\
\hline $\mathrm{TO} \rightarrow \mathrm{TM}$ & 0.418 & 0.000 & 0.380 & 0.000 & 0.039 & 0.315 & ns \\
\hline $\mathrm{AM} \rightarrow \mathrm{IA}$ & 0.325 & 0.000 & 0.342 & 0.000 & 0.017 & 0.599 & ns \\
\hline $\mathrm{TM} \rightarrow \mathrm{IA}$ & 0.607 & 0.000 & 0.539 & 0.000 & 0.068 & 0.187 & ns \\
\hline $\mathrm{CP} \rightarrow \mathrm{IA}$ & 0.179 & 0.000 & 0.155 & 0.004 & 0.024 & 0.353 & ns \\
\hline $\mathrm{NP} \rightarrow \mathrm{IA}$ & 0.362 & 0.000 & 0.341 & 0.000 & 0.021 & 0.385 & ns \\
\hline $\mathrm{MP} \rightarrow \mathrm{IA}$ & 0.313 & 0.000 & 0.300 & 0.000 & 0.013 & 0.430 & ns \\
\hline
\end{tabular}

Table IX.

PLS-MGA (gender and age)

Notes: AA, attitude toward ATMs; AO, attitude toward online banking; AM, attitude toward mobile banking; TA, trust in ATMs; TO, trust in online banking; TM, trust in mobile banking; CP, coercive pressure; $\mathrm{NP}$, normative pressure; MP, mimetic pressure; IA, intention to adopt mobile banking; G1, males; G2, females; G3, age < 30; G4, age > 30; G5, age < 50; G6, age > 50; diff, difference; Sig., significance

\section{Discussion and implications}

The main goal of this study is to propose and test a model aiming at investigating how the customers' responses in terms of attitudes toward and trust in mature SSTs along with social factors influence the customers' intentions to adopt a newly introduced SST, namely, mobile banking. Accordingly, drawing from the TRA (Fishbein and Ajzen, 1975), the SSTs intention to change behavior model (Curran and Meuter, 2007), the trust transference literature (Lee et al., 2007) and the social contagion theory (Shi et al., 2008), this study proposes an integrative model that simultaneously investigates the transference effects of attitudes, trust and contagious impacts of social pressure on mobile banking adoption intentions.

The results lend support to the study's conceptual model which emphasizes that different transference and contagious effects occur in the context of the adoption of a new SST. These effects are manifested through the transfer of attitudes toward and trust in 
previous SSTs as well as the contagious effects of social influences (i.e. coercive pressure, normative pressure and mimetic pressure).

The results show that attitudes toward both ATMs and online banking significantly predict attitude toward mobile banking. Particularly, a favorable attitude toward online banking has a stronger impact on attitude toward mobile banking compared to the effect of attitude toward ATMs. The results also support the significant effects of trust in ATMs and trust in online banking on trust in mobile banking. As expected, the transference of trust in online banking to mobile banking is stronger than the transference effect of trust in ATMs. In turn, swiftly formed attitudes toward and trust in mobile banking along with coercive pressure, normative pressure and mimetic pressure significantly affect customers' intentions to adopt mobile banking. Taken together, these results suggest that established attitudes toward and trust in widespread SSTs are instrumental in prompting customers to develop attitudes toward and trust in a newly introduced SST. Consequently, both attitude and trust contagions lead the current research to advance the notion of SSTs portfolio molecule, building on Lederer and Hill (2001). This molecular perspective implies that SSTs "take the form of atoms" (Lederer and Hill, 2001, p. 126). That is, distinct SSTs operate as interweaved atoms with synergistic (or conflicting) connections rather than free and isolated atoms. Indeed, one major criticism of prior research lies in the fact that, with the exception of a handful of studies, most technology adoption studies have focused almost exclusively on the new echannel per se without considering the impact of the old ones. Indeed, customers have the choice between different options to conduct their banking transactions. However, what is much less clear is how previous service encounters with a familiar channel will influence new attitudes and intention to adopt a new service channel (Wang et al., 2012). This study contributes to the extant literature on mobile banking adoption by highlighting these contagion effects. From a managerial perspective, this view helps banks to develop "an optimal multi-channel mix" strategy (Schramm-Klein et al., 2011, p. 509).

\subsection{Theoretical implications}

This study contributes to the SSTs adoption literature in several ways. First, our conceptual model contributes to the extant literature by offering an integrative synthesis of contagion effects. In fact, the present study represents a first step toward generating new insights into the role of the joint effects of attitudes, trust and social influences in the adoption of a new SST. That is, to the best of our knowledge, this study is the first to propose an integrative model in the sense that it considers simultaneously the roles of attitudes and trust transfer as well as social contagion in the adoption of a new SST. Prior research does not look at attitudes and trust transference and social contagion effects on SST adoption from a concomitant perspective. Considering these variables simultaneously is likely to enhance the explanatory power of SST adoption models.

Second, the current study, as opposed to previous research, investigates to which extent preceding SSTs already adopted by customers play a role in facilitating the adoption of a newly introduced SST such as mobile banking. Pointedly, the literature review reveals that only a few studies investigated SST adoption from a multi-channel perspective that takes into account the interplay and synergetic effects between various channel platforms. In fact, a great deal of previous research investigates the adoption of a new SST without considering the spill over effects of the preceding SSTs (cf. Wang et al., 2012). This perspective is somewhat unrealistic since past technology-based service encounters play a significant role in the adoption of a new SST (cf. Curran and Meuter, 2007; Wang et al., 2012). It comes as no surprise that focusing exclusively on the new SST (i.e. in isolation without considering the other mature channels) can be criticized. 
IJBM

37,1

88

Third and building on the SST's intention to change behavior model (Curran and Meuter, 2007), this study provides clear evidence to suggest that attitudes transfer across channels. Familiar products/services serve as the basis for customers' inferences regarding unknown products/services. In other words, customers deduce their new attitudes from their well-established prior ones. Thus, favorable assessments of familiar products/services help customers assign to new products/services favorable evaluations. In the context of the current research, attitudes toward ATMs and online banking (familiar service encounters) jointly create a swift attitude toward mobile banking. Accordingly, attitude is likely to progress from mature channels to the new one. Customers mainly draw their appraisals of mobile banking from the history of their past interactions with other bank channels. Therefore, prior channels transmit evaluative signals to the new channel. Customers use this heuristic cue in order to counterbalance their lack of experience regarding the new channel.

Fourth, the current research also provides strong evidence supporting the trust transfer theory (Lee et al., 2007). Aligned with the reasoning explaining attitude transfer, trust is likely to transit across channels. When customers lack experience with mobile channels, they tend to form their mobile trust depending on their prior trust in familiar channels. Trust in ATMs and trust in online banking convey strong indications and clues helping customers to build their trust in mobile banking. To the extent that ATMs and online banking are perceived as highly trustworthy, they are thus deemed satisfactory "proof sources" (Bock et al., 2012, p. 99) to ascribe high confidence in mobile banking.

Fifth, the current study extends research dealing with the effects of social pressure on SST adoption. Prior research merely focuses on the role of social acceptance (i.e. others' approval) in a new technological adoption. Nevertheless, this study demonstrates that, along with social acceptance (i.e. normative pressure), other forms of social pressure also play a significant role in prompting customers to adopt a newly introduced SST, namely, coercive pressure and mimetic pressure. All aspects of social pressure significantly affect customers' intentions to adopt mobile banking. In other words, customers tend to adopt a new SST because they need to comply with the rules of a perceived powerful entity, to obtain the approval of significant and/or similar others and to identify themselves with their admired ones. Particularly, normative pressure and mimetic pressure have more impact on customers' adoption intentions compared to the impact of coercive pressure.

\subsection{Practical implications}

Previous research has been less active in uncovering contagion-based mechanisms in order to broaden our understanding of the predictors of intention to adopt a new SST in a multi-channel context. In other words, how could contagion affect technology acceptance without customer's prior knowledge or experience. In light of this, it is thus critical to integrate attitude, trust and social contagions as key elements in the inferential decision-making process. To the best of the authors' knowledge, no particular attention has been given to explore the combined roles of the transferability of attitudes and trust across the bank's delivery channels and the contagion of social pressure in technology adoption. The current study proposes a comprehensive research model which will help banks to be in a better position to entice their clients to adopt mobile banking by capitalizing on their well-established SSTs and social contagion.

Taken as a whole, the study's results hint at some practical and worthwhile guidelines for banks that can be achieved in communication campaigns to boost mobile banking adoption. Since customers are exposed to different channels to carry out their banking transactions, "better strategies can be developed to manage and coordinate multiple service delivery options" (Wang et al., 2012, p. 54). This situation can be reached if banks get a deep comprehension of the combined contagious effects that are likely to occur during the pre-adoption stage. The current research demonstrates that banks can take advantage of 
the transference effects of the established attitudes toward and trusting beliefs in their mature SSTs as well as the contagious social effects in enticing their customers to adopt a newly introduced SST.

Thus, customers make a good first impression on the new system drawing from their judgments of the mature ones. In other words, attitude contagion is a proxy indicator which helps customers to create a favorable evaluation of mobile banking. They can leverage the established favorable attitudes toward ATMs and online banking (with more emphasis on online banking) to foster positive attitudes toward mobile banking. In line with Kuan and Bock (2007), banks can propose multi-channel membership programs to encourage heavy users of online banking and ATMs to try the mobile channel. They can allow those customers to benefit from loyalty points, discounts or bonuses whenever they try or use mobile banking to make transactions (Kuan and Bock, 2007, Lee et al., 2007).

Likewise, the results clearly indicate that, in order for banks to entice customers to adopt mobile banking, fostering customers' trust in that platform is of a paramount significance. In fact, the relative importance of trust in mobile banking is higher than the relative importance of the other antecedents of mobile baking adoption intentions. That is, trust in mobile banking is the quintessential factor that will lead customers to use mobile banking. Nevertheless, how does a bank nurture trust in a thing that is relatively new? Table VII hints to the fact that banks can nurture trust in mobile banking through leveraging, among others, their established customers' trust in their preceding channels such as ATMs and online banking. In fact, trust in ATMs and online banking, as indicated in Table VII, are equally two important antecedents to trust in mobile banking. Thus, the results suggest that trusting beliefs in ATMs and online banking are likely to be used as strong heuristic decision rules on which one can infer mobile banking's trustworthiness. As such, customers make inferences about the reliability and level of safety and security of the new system on the basis of their cumulative satisfactory experience with old channels. Therefore, banks can capitalize on the established trust in ATMs and online banking (with more emphasis on online banking) in order to gain a swift trust in mobile banking among their customers. For example, a bank may launch an advertising campaign incentivizing its clients to adopt mobile banking by reminding them of the bank's commitment to protect their privacy and provide them with secure, convenient and effective solutions to complete their banking transactions as with their ATMs and online interfaces.

Banks can also count on different forms of social pressure to influence the adoption rates of mobile banking. As mentioned above, normative pressure has a stronger effect and higher relative importance compared to coercive pressure and mimetic pressure in shaping customers' intentions to adopt mobile banking. That is, a favorable recommendation regarding a new SST from a friend or a family member is a key factor in the adoption of a technology-based interface in a banking context. Banks are well-advised to rely on social networks through the spread of word-of-mouth by mobile banking adopters (e.g. peers' recommendations via e-mails) to speed up the adoption rate among the non-adopters. This means that banks rely on actual mobile banking users in order to encourage adoption among the non-users. For example, one strategy is to design reward programs for current users who would attract and bring in new ones. Another strategy is to rely on influential and successful people (e.g. celebrities, well-known businesspeople, politicians, athletes, etc.) as advocates of mobile banking. With respect to coercive pressure, banks can, for example, seek collaborations and partnerships with other private or public organizations (service providers or public authorities) in order to require their customers to use mobile banking as the only means of payment (e.g. water and electricity bills). That is, they can choose to make some banking services exclusively accessed through mobile banking. 
IJBM

37,1

90

\section{Limitations and future research directions}

This study has some limitations that may offer opportunities for future research. First, the study has been conducted in only one county (i.e. France). As such, the findings cannot be generalized to other countries where the level of information technology infrastructure and legal framework as well as customers' exposure to and experience with SSTs could be different (Al-Ajam and Md Nor, 2015). Additional studies in other countries are needed to further enhance the generalizability of our tested model. In the same vein, this study has been conducted in a banking context. It would be interesting to replicate the study's model in other contexts where SSTs are in use.

Although the current research adopts the same instrument used by previous studies, the use of three Likert-scale items for trust is oversimplified as traditionally trust is based on beliefs about ability ("group of skills, competencies, and characteristics that enable a party to have influence within some specific domain"), integrity (the extent to which "the trustee adheres to a set of principles that the trustor finds acceptable") and benevolence ("the extent to which a trustee is believed to want to do good to the trustor, aside from an egocentric profit motive”) (Mayer et al., 1995, pp. 717-719). Including these constructs in the model in a separate way will offer a fruitful avenue for future research. This procedure is likely to provide a much more thorough and detailed comprehension of trust transfer by studying the transfer of ability, integrity and benevolence across channels. In other words, it can yield new insights regarding how beliefs about ability, integrity and benevolence of the bank in old channels (ATMs and online banking) affects beliefs about ability, integrity and benevolence of the bank in the new channel (mobile banking).

In addition, the study deliberately focuses only on the interplay between SSTs (i.e. ATMs, online banking and mobile banking) and the contagious effects of social influences. Aside from what is confirmed, the roles of interpersonal service encounters (e.g. attitude toward the offline bank and trust in the offline bank), technical features (e.g. level of complexity, perceived usefulness and security) and individual characteristics (e.g. psychological factors) in affecting intention to adopt mobile banking need to also be addressed in more comprehensive models.

Finally, the current research urges the need for future studies to understand the level of a customer's involvement in SSTs. In that perspective, one can argue that "cognitive misers," here customers who are not highly involved in SSTs, are likely to be influenced by mental shortcuts (e.g. attitudes toward existing SSTs and social influences) in their adoption of a new SST (Garrity et al., 2005). In contrast, customers who are highly involved in SSTs are likely to adopt a new one, by weighing the benefits and pitfalls associated with that new platform. They are likely to be influenced by the central route of persuasion (e.g. benefit-cost analysis of the adoption of a new technology) rather than by peripheral elements (e.g. attitudes transfer and social influences). The elaboration likelihood model (Petty and Cacioppo, 1981) is a good theoretical foundation upon which future research can determine under which conditions the attitudes and trust spread and how social contagion operates better.

\section{Notes}

1. SST is defined as "a technological interface that allows customers to produce and consume services without direct assistance from employees" (Curran and Meuter, 2007, p. 283).

2. In this study, contagion, transfer, transferability and transference are used interchangeably.

3. The same definition will also be adopted to define attitude toward ATMs and attitude toward online banking. 


\section{References}

Al-Ajam, A.S. and MdNor, K. (2015), "Challenges of adoption of internet banking service in Yemen", International Journal of Bank Marketing, Vol. 33 No. 2, pp. 178-194.

Alba, J.W. and Hutchinson, J.W. (1987), "Dimensions of consumer expertise", Journal of Consumer Research, Vol. 13 No. 4, pp. 411-454.

Albesa, J.G. (2007), "Interaction channel choice in a multichannel environment, an empirical study", International Journal of Bank Marketing, Vol. 25 No. 7, pp. 490-506.

Amin, H., Abdul-Rahman, A.-R. and Abdul-Razak, D. (2016), "Malaysian consumers' willingness to choose Islamic mortgage products: an extension of the theory of interpersonal behavior", International Journal of Bank Marketing, Vol. 34 No. 6, pp. 868-884.

Anderson, J. and Gerbing, D. (1984), "The effect of sampling error on convergence, improper solutions, and goodness-of-fit indices for maximum likelihood confirmatory factor analysis", Psychometrika, Vol. 49 No. 2, pp. 155-173.

Andrews, L. and Bianchi, C. (2013), "Consumer internet purchasing behavior in Chile", Journal of Business Research, Vol. 66 No. 10, pp. 1791-1799.

Angst, C.M., Agarwal, R., Smith, R.H., Sambamurthy, V. and Kelley, K. (2010), "Social contagion and information technology diffusion: the adoption of electronic medical records in US hospitals", Management Science, Vol. 56 No. 8, pp. 1219-1241.

Bagozzi, R.P. (1993), "On the neglect of volition in consumer research: a critique and proposal", Psychology \& Marketing, Vol. 10 No. 3, pp. 215-237.

Baker, E.W., Al-Gahtani, S.S. and Hubona, G.S. (2007), "The effects of gender and age on new technology implementation in a developing country testing the theory of planned behavior (TPB)", Information Technology \& People, Vol. 20 No. 4, pp. 352-375.

Belanche, D., Casaló, L.V., Flavián, C. and Schepers, J. (2014), "Trust transfer in the continued usage of public e-services", Information \& Management, Vol. 51 No. 6, pp. 627-640.

Bhattacherjee, A. (2000), "Acceptance of e-commerce services: the case of electronic brokerages", IEEE Transactions on Systems, Man, and Cybernetics Part A: Systems and Humans, Vol. 30 No. 4, pp. 411-420.

Bitner, M.J., Brown, S.W. and Meuter, M.L. (2000), "Technology infusion in service encounters”, Journal of the Academy of Marketing Science, Vol. 28 No. 1, pp. 138-149.

Bobbitt, L.M. and Dabholkar, P.A. (2001), "Integrating attitudinal theories to understand and predict use of technology-based self-service", International Journal of Service Industry Management, Vol. 12 No. 5, pp. 423-450.

Bock, G.W., Lee, J., Kuan, H.H. and Kim, J.H. (2012), "The progression of online trust in the multi-channel retailer context and the role of product uncertainty", Decision Support Systems, Vol. 53 No. 1, pp. 97-107.

Brislin, R.W. (1970), "Back-translation for cross-cultural research”, Journal of Cross-Cultural Psychology, Vol. 1 No. 3, pp. 185-216.

Brown, S.A. and Venkatesh, V. (2005), "Model of adoption of technology in households: a baseline model test and extension incorporating household life cycle”, MIS Quarterly, Vol. 29 No. 3, pp. 399-426.

Brown, S.A., Dennis, A.R. and Venkatesh, V. (2010), "Predicting collaboration technology use: integrating technology adoption and collaboration research", Journal of Management Information Systems, Vol. 27 No. 2, pp. 9-53.

Brown, S.A., Venkatesh, V. and Bala, H. (2006), "Household technology use: integrating household life cycle and the model of adoption of technology in households", The Information Society, Vol. 22 No. 4, pp. 205-218.

Calvo-Mora, A., Navarro-García, A., Rey-Moreno, M. and Periañez-Cristobal, R. (2016), "Excellence management practices, knowledge management and key business results in large organisations and SMEs: a multi-group analysis", European Management Journal, Vol. 34 No. 6, pp. 661-673. 
IJBM

37,1

Curran, J.M. and Meuter, M.L. (2007), "Encouraging existing customers to switch to self-service technologies: put a little fun in their lives", Journal of Marketing Theory and Practice, Vol. 15 No. 4, pp. 283-298.

Diamantopoulos, A., Sarstedt, M., Fuchs, C., Wilczynski, P. and Kaiser, S. (2012), "Guidelines for choosing between multi-item and single-item scales for construct measurement: a predictive validity perspective", Journal of the Academy of Marketing Science, Vol. 40 No. 3, pp. 434-449.

Eagly, A.A. and Chaiken, S. (1993), The Psychology of Attitudes, Harcourt Brace, Fort Worth, TX.

Eriksson, K. and Nilsson, D. (2007), "Determinants of the continued use of self-service technology: the case of internet banking", Technovation, Vol. 27 No. 4, pp. 159-167.

Falk, T., Schepers, J., Hammerschmidt, M. and Bauer, H.H. (2007), "Identifying cross-channel dissynergies for multichannel service providers", Journal of Service Research, Vol. 10 No. 2, pp. 143-160.

Fishbein, M. and Ajzen, I. (1975), Belief, Attitude, Intention and Behavior: An Introduction to Theory and Research, Addison-Wesley, Reading, MA.

Flavián, C., Guinalíu, M. and Torres, E. (2006), "How bricks-and-mortar attributes affect online banking adoption”, International Journal of Bank Marketing, Vol. 24 No. 6, pp. 406-423.

Fornell, C. and Larcker, D.F. (1981), "Evaluating structural equation models with unobservable variables and measurement error", Journal of Marketing Research, Vol. 18 No. 3, pp. 39-50.

Garrity, E.J., Glassberg, B., Kim, Y.J., Sanders, G.L. and Shin, S.K. (2005), "An experimental investigation of web-based information systems success in the context of electronic commerce", Decision Support Systems, Vol. 39 No. 3, pp. 485-503.

Geisser, S. (1974), "A predictive approach to the random effects model", Biometrika, Vol. 61 No. 1, pp. 101-107.

Grob, S. and Benn, S. (2014), "Conceptualising the adoption of sustainable procurement: an institutional theory perspective", Australasian Journal of Environmental Management, Vol. 21 No. 1, pp. 11-21.

Ha, S. and Stoel, L. (2009), "Consumer e-shopping acceptance: antecedents in a technology acceptance model”, Journal of Business Research, Vol. 62 No. 5, pp. 565-571.

Hahn, K.H. and Kim, J. (2009), "The effect of offline brand trust and perceived internet confidence on online shopping intention in the integrated multi-channel context", International Journal of Retail \& Distribution Management, Vol. 37 No. 2, pp. 126-141.

Hair, J.F., Ringle, C.M. and Sarstedt, M. (2011), "PLS-SEM: indeed a silver bullet”, Journal of Marketing Theory and Practice, Vol. 19 No. 2, pp. 139-151.

Hair, J.F., Hult, G.T.M., Ringle, C.M. and Sarstedt, M. (2014), A Primer on Partial Least Squares Structural Equation Modeling, 1st ed., Sage, Thousand Oaks, CA.

Hair, J.F., Hult, G.T.M., Ringle, C.M. and Sarstedt, M. (2017), A Primer on Partial Least Squares Structural Equation Modeling, 2nd ed., Sage, Thousand Oaks, CA.

Henseler, J., Ringle, C.M. and Sarstedt, M. (2016), “Testing measurement invariance of composites using partial least squares", International Marketing Review, Vol. 33 No. 3, pp. 405-431.

Herhausen, D., Binder, J., Schoegel, M. and Herrmann, A. (2015), "Integrating bricks with clicks: retailer-level and channel-level outcomes of online-offline channel integration", Journal of Retailing, Vol. 91 No. 2, pp. 309-325.

Hoffmann, A.O.I. and Ketteler, D. (2015), "How experiences with trading a company's stock influence customer attitudes and purchasing behavior", International Journal of Bank Marketing, Vol. 33 No. 7, pp. 963-992. 
Hulin, C., Cudeck, R., Netemeyer, R., Dillon, W.R., McDonald, R. and Bearden, W. (2001), "Measurement", Journal of Consumer Psychology, Vol. 10 Nos 1/2, pp. 55-69.

Kantar TNS (2016), "Money goes mobile", available at: www.tnsglobal.com/sites/default/files/ whitepaper/tns-mobile-life-money-goes-mobile.html (accessed August 25, 2016).

Keller, K.L. (1987), "Memory factors in advertising: the effect of advertising retrieval cues on brand evaluations", Journal of Consumer Research, Vol. 14 No. 3, pp. 316-333.

Keller, K.L. (1993), “Conceptualizing, measuring, and managing customer-based brand equity”, Journal of Marketing, Vol. 57 No. 1, pp. 1-22.

Kim, G., Shin, B. and Lee, H.G. (2009), "Understanding dynamics between initial trust and usage intentions of mobile banking”, Information Systems Journal, Vol. 19 No. 3, pp. 283-311.

Kim, H.-W., Xu, Y. and Koh, J. (2004), "A comparison of online trust building factors between potential customers and repeat customers", Journal of the Association for Information Systems, Vol. 5 No. 10, pp. 392-420.

Klein, J. and Dawar, N. (2004), “Corporate social responsibility and consumers' attributions and brand evaluations in a product-harm crisis", International Journal of Research in Marketing, Vol. 21 No. 3, pp. 203-217.

Koufaris, M. and Hampton-Sosa, W. (2004), "The development of initial trust in an online company by new customers", Information \& Management, Vol. 41 No. 3, pp. 377-397.

Kuan, H.-H. and Bock, G.-W. (2007), "Trust transference in brick and click retailers: an investigation of the before-online-visit phase", Information \& Management, Vol. 44 No. 2, pp. 175-187.

Kuan, H.-H., Bock, G.-W. and Lee, J. (2007), "A cognitive dissonance perspective of customers' online trust in multi-channel retailers", The 15th Annual Conference of the European Conference on Information Systems, St Gallen, pp. 13-23.

Lankton, N.K., McKnight, D.H., Wright, R.T. and Thatcher, J.B. (2016), "Using expectation disconfirmation theory and polynomial modeling to understand trust in technology", Information Systems Research, Vol. 27 No. 1, pp. 197-213.

Laukkanen, T. (2016), "Consumer adoption versus rejection decisions in seemingly similar service innovations: the case of the internet and mobile banking", Journal of Business Research, Vol. 69 No. 7, pp. 2432-2439.

Lederer, C. and Hill, S. (2001), "See your brands through your customers' eyes", Harvard Business Review, Vol. 79 No. 6, pp. 125-133.

Lee, K.C., Kang, I. and McKnight, D.H. (2007), “Transfer from offline trust to key online perceptions: an empirical study", IEEE Transactions on Engineering Management, Vol. 54 No. 4, pp. 729-741.

Lee, K.-W., Tsai, M.-T. and Lanting, M.C.L. (2011), "From marketplace to marketspace: investigating the consumer switch to online banking", Electronic Commerce Research and Applications, Vol. 10 No. 1, pp. 115-125.

Lin, J., Lu, Y., Wang, B. and Wei, K.K. (2011), “The role of inter-channel trust transfer in establishing mobile commerce trust", Electronic Commerce Research and Applications, Vol. 10 No. 6, pp. 615-625.

Lin, J., Lu, Y., Wang, B. and Wei, K.K. (2014), "The role of inter-channel trust transfer in establishing mobile commerce trust", Electronic Commerce Research and Applications, Vol. 10 No. 6, pp. 615625.

Loken, B. (2006), "Consumer psychology: categorization, inferences, affect, and persuasion", Annual Review of Psychology, Vol. 57 No. 1, pp. 453-485.

Lowry, P.B., Vance, A., Moody, G., Beckman, B. and Read, A. (2008), "Explaining and predicting the impact of branding alliances and web site quality on initial consumer trust of e-commerce web sites", Journal of Management Information Systems, Vol. 24 No. 4, pp. 199-224.

Lu, J., Liu, C., Yu, C.S. and Wang, K. (2008), "Determinants of accepting wireless mobile data services in China”, Information \& Management, Vol. 45 No. 1, pp. 52-64. 
IJBM

37,1

94

McKnight, D.H., Carter, M., Thatcher, J.B. and Clay, P.F. (2011), "Trust in a specific technology: an investigation of its components and measures", ACM Transactions on Management Information Systems, Vol. 12 No. 1, pp. 12-25.

MacKenzie, S.B., Lutz, R.J. and Belch, G.E. (1986), "The role of attitude toward the Ad as a mediator of advertising effectiveness: a test of competing explanations", Journal of Marketing Research, Vol. 23 No. 2, pp. 130-143.

Martins, C., Oliveira, T. and Popovic, A. (2014), "Understanding the internet banking adoption: a unified theory of acceptance and use of technology and perceived risk application", International Journal of Information Management, Vol. 34 No. 1, pp. 1-13.

Mayer, R.C., Davis, J.H. and Schoorman, F.D. (1995), “An integrative model of organizational trust”, The Academy of Management Review, Vol. 20 No. 3, pp. 709-734.

Mitchell, A.A. and Olson, J.C. (1981), "Are product attribute beliefs the only mediator of advertising effects on brand attitude?", Journal of Marketing Research, Vol. 18 No. 3, pp. 318-332.

Morgan, R.M. and Hunt, S.D. (1994), "The commitment-trust theory of relationship marketing”, Journal of Marketing, Vol. 58 No. 3, pp. 20-38.

Muk, A. and Chung, C. (2015), "Applying the technology acceptance model in a two-country study of SMS advertising", Journal of Business Research, Vol. 68 No. 1, pp. 1-6.

Patsiotis, A.G., Webber, D.J. and Hughes, T. (2013), "Internet shopping and internet banking in sequence: an explanatory case study", Journal of Financial Services Marketing, Vol. 18 No. 4, pp. 285-300.

Peters, T., Işık, Ö., Tona, O. and Popovič, A. (2016), "How system quality influences mobile BI use: the mediating role of engagement", International Journal of Information Management, Vol. 36 No. 5 , pp. 773-783.

Petty, R.E. and Cacioppo, J.T. (1981), Attitudes and Persuasion: Classic and Contemporary Approaches, Wm. C. Brown, Dubuque, IA.

Podsakoff, P.M., MacKenzie, S.B., Lee, J.-Y. and Podsakoff, N.P. (2003), "Common method biases in behavioral research: a critical review of the literature and recommended remedies", Journal of Applied Psychology, Vol. 88 No. 5, pp. 879-903.

Püschel, J., Mazzon, J.A. and Hernandez, J.M.C. (2010), "Mobile banking: proposition of an integrated adoption intention framework", International Journal of Bank Marketing, Vol. 28 No. 5, pp. 389-409.

Ramayah, T., Rouibah, K., Gopi, M. and Rangel, G.J. (2009), “A decomposed theory of reasoned action to explain intention to use internet stock trading among Malaysian investors", Computers in Human Behavior, Vol. 25 No. 6, pp. 1222-1230.

Reinders, M.J., Dabholkar, P.A. and Frambach, R.T. (2008), "Consequences of forcing consumers to use technology-based self-service”, Journal of Service Research, Vol. 11 No. 2, pp. 107-123.

Riquelme, H.E. and Rios, R.E. (2010), "The moderating effect of gender in the adoption of mobile banking", International Journal of Bank Marketing, Vol. 28 No. 5, pp. 328-341.

Robinson, L., Marshall, G.W. and Stamps, M.B. (2005), "Sales force use of technology: antecedents to technology acceptance", Journal of Business Research, Vol. 58 No. 12, pp. 1623-1631.

Schierz, P.G., Schilke, O. and Wirtz, B.W. (2010), "Understanding consumer acceptance of mobile payment services: an empirical analysis", Electronic Commerce Research and Applications, Vol. 9 No. 3, pp. 209-216.

Schoorman, F.D., Mayer, R.C. and Davis, J.H. (2007), "An integrative model of organizational trust: past, present, and future", Academy of Management Review, Vol. 32 No. 2, pp. 344-354.

Schramm-Klein, H., Wagner, G., Steinmann, S. and Morschett, D. (2011), "Cross-channel integration - is it valued by customers?", The International Review of Retail, Distribution and Consumer Research, Vol. 21 No. 5, pp. 501-511.

Shaikh, A.A. and Karjaluoto, H. (2015), "Mobile banking adoption: a literature review", Telematics and Informatics, Vol. 32 No. 1, pp. 129-142.

Sherer, S.A., Meyerhoefer, C.D. and Peng, L. (2016), "Applying institutional theory to the adoption of electronic health records in the US”, Information \& Management, Vol. 53 No. 5, pp. 570-580. 
Shi, W., Shambare, N. and Wang, J. (2008), "The adoption of internet banking: an institutional theory perspective", Journal of Financial Services Marketing, Vol. 12 No. 4, pp. 272-286.

Shimp, T.A. (1981), "Attitude toward the ad as a mediator of consumer brand choice", Journal of Advertising, Vol. 10 No. 2, pp. 9-48.

Simonin, B.L. and Ruth, J.A. (1998), "Is a company known by the company it keeps? Assessing the spillover effects of brand alliances on consumer brand attitudes", Journal of Marketing Research, Vol. 35 No. 1, pp. 30-42.

Song, P., Xu, H., Techatassanasoontorn, A. and Zhang, C. (2011), "The influence of product integration on online advertising effectiveness", Electronic Commerce Research and Applications, Vol. 10 No. 3, pp. 288-303.

Song, P., Zhang, C., Chen, W. and Huang, L. (2009), "Understanding usage-transfer behavior between nonsubstitutable technologies: evidence from instant messenger and portal”, IEEE Transactions on Engineering Management, Vol. 56 No. 3, pp. 412-424.

Stewart, K.J. (2003), “Trust transfer on the World Wide Web”, Organization Science, Vol. 14 No. 1, pp. 5-17.

Stewart, K.J. (2006), "How hypertext links influence consumer perceptions to build and degrade trust online", Journal of Management Information Systems, Vol. 23 No. 1, pp. 183-210.

Stone, M. (1974), "Cross-validatory choice and assessment of statistical predictions", Journal of the Royal Statistical Society, Vol. 36 No. 2, pp. 111-147.

Taylor, S. and Todd, P. (1995), "Understanding information technology usage: a test of competing models", Information Systems Research, Vol. 6 No. 2, pp. 144-176.

Teo, H.H., Wei, K.K. and Benbasat, I. (2003), "Predicting intention to adopt interorganizational linkages: an institutional perspective", MIS Quarterly, Vol. 27 No. 1, pp. 19-49.

Thatcher, J.B., McKnight, D.H., Baker, E.W., Arsal, R.E. and Roberts, N.H. (2011), "The role of trust in postadoption IT exploration: an empirical examination of knowledge management systems", IEEE Transactions on Engineering Management, Vol. 58 No. 1, pp. 56-70.

Varvoglis, T. and Sirgy, J.M. (1984), "The interrelationship between utilitarian and value-expressive store image attributes", in Jay, D.L. (Ed.), Developments in Marketing Science, Vol. 7, Academy of Marketing Science, Kalmazoo, MI, pp. 27-31.

Venkatesh, V., Brown, S.A., Maruping, L.M. and Bala, H. (2008), "Predicting different conceptualizations of system use: the competing roles of behavioral intention, facilitating conditions, and behavioral expectation", MIS Quarterly, Vol. 32 No. 3, pp. 483-502.

Venkatesh, V., Morris, M.G., Davis, G.B. and Davis, F.D. (2003), "User acceptance of information technology: toward a unified view”, MIS Quarterly, Vol. 27 No. 3, pp. 425-478.

Verhagen, T. and van Dolen, W. (2009), "Online purchase intentions: a multi-channel store image perspective”, Information \& Management, Vol. 46 No. 2, pp. 77-82.

Walden, E.A. and Browne, G.J. (2009), "Sequential adoption theory: a theory for understanding herding behavior in early adoption of novel technologies", Journal of the Association for Information Systems, Vol. 10 No. 1, pp. 31-62.

Wang, C., Harris, J. and Patterson, P.G. (2012), "Customer choice of self-service technology: the roles of situational influences and past experience”, Journal of Service Management, Vol. 23 No. 1, pp. 54-78.

Wang, N., Shen, X.-L. and Sun, Y. (2013), "Transition of electronic word-of-mouth services from web to mobile context: a trust transfer perspective", Decision Support Systems, Vol. 54 No. 3, pp. 1394-1403.

Xie, C., Bagozzi, R.P. and Troye, S.V. (2008), "Trying to prosume: toward a theory of consumers as cocreators of value", Journal of the Academy of Marketing Science, Vol. 36 No. 1, pp. 109-122.

Yang, S., Lu, Y. and Chau, P.Y.K. (2013), "Why do consumers adopt online channel? An empirical investigation of two channel extension mechanisms", Decision Support Systems, Vol. 54 No. 2, pp. 858-869.

Yang, Y., Liu, Y., Li, H. and Yu, B. (2015), "Understanding perceived risks in mobile payment acceptance", Industrial Management \& Data Systems, Vol. 115 No. 2, pp. 253-269. 
Yap, K.B., Wong, D.H., Loh, C. and Bak, R. (2010), "The development of initial trust in an online company by new customers", International Journal of Bank Marketing, Vol. 28 No. 1, pp. 27-46.

Zhou, T. (2011), "Understanding online community user participation: a social influence perspective", Internet Research, Vol. 21 No. 1, pp. 67-81.

Zhou, T. (2012), "Examining mobile banking user adoption from the perspectives of trust and flow experience", Information Technology and Management, Vol. 13 No. 1, pp. 27-37.

Zhou, T. (2013), "An empirical examination of continuance intention of mobile payment services", Decision Support Systems, Vol. 54 No. 2, pp. 1085-1091.

\section{Further reading}

Chin, W.W. (1998), "Issues and opinion on structural equation modeling", MIS Quarterly, Vol. 22 No. 1, pp. 7-15.

Preacher, K.J. and Hayes, A.F. (2008), "Asymptotic and resampling strategies for assessing and comparing indirect effects in multiple mediator models", Behavior Research Methods, Vol. 40 No. 3, pp. 879-891.

\section{About the authors}

Walid Chaouali is currently Doctoral Student at the Faculty of Economics and Management, University of Sfax, Tunisia. He is Member of the Center of Applied Research in Business Relationships and Economics at Institut Supérieur de Gestion, Tunis University, Tunisia as well as Member of a Research Group on Customers' Experience and Social Media at Laval University, Canada. His research interests include customer adoption of information technology, online consumer behavior and services marketing. His main publications have appeared in Journal of Retailing and Consumer Services, Journal of High Technology Management Research and Telematics and Informatics.

Kamel El Hedhli is Associate Professor of Marketing at the College of Business and Economics, Qatar University. He received a PhD Degree in Business Administration (marketing) from HEC Montreal, Canada. His research interests lie in the intersection of consumer psychology, retailing and services, consumer well-being/quality-of-Life studies and cross-cultural research. His research has appeared in various academic journals such as the Journal of Business Research, Journal of Retailing and Consumer Services, International Journal of Consumer Studies, International Journal of Quality and Service Sciences and Perceptual and Motor Skills. Kamel El Hedhli is the corresponding author and can be contacted at:khedhli@qu.edu.qa

For instructions on how to order reprints of this article, please visit our website: 